This document is the accepted version of work published in its final form in Helvetica Chimica Acta, Wiley. It can be found at:

https://onlinelibrary.wiley.com/doi/abs/10.1002/hlca.201900180

To cite this publication:

Lemonier, S.; Marty, J.-D.; Fitremann, J. Polysiloxanes Modified by Thiol-Ene Reaction and

Their Interaction with Gold Nanoparticles. Helvetica Chimica Acta 2019, 102 (11), e1900180.

\title{
Polysiloxanes modified by thiol-ene reaction and their interaction with gold nanoparticles
}

Stéphane Lemonier, Jean-Daniel Marty, Juliette Fitremann*

IMRCP, Université de Toulouse, CNRS, Bat 2R1, 118 Route de Narbonne, 31062 Toulouse Cedex 9, France.

fitremann@chimie.ups-tlse.fr

\section{Abstract}

A poly(vinylmethyl-co-dimethyl)siloxane has been functionalized with phenylethanethiol, $\mathrm{N}$ methylmercaptoacetamide and heptadecafluoro-1-decanethiol by a thermal radical thiol-ene reaction initiated by azobisisobutyronitrile. The resulting polymers were obtained in good yields with most of the time a complete conversion of the vinyl groups. The reaction also preserved the fragile polysiloxane backbone. The polymer, grafted with about $25 \%$ of mercapto-acetamide groups is soluble in polar solvents such as dimethylformamide and dimethylsulfoxide, opening the way for further functionalization with polar molecules such as unprotected carbohydrates. Spherical and branched gold nanoparticles were coated with these polymers. This coating induced a surface resonance plasmon shift resulting from the interaction of the grafted polysiloxanes with the nanoparticle surface. The shift can be explained by the variation of the refractive index of the side groups but may be also related to the selforganization of polysiloxanes and their interactions with the gold surface depending on their polarity.

\section{Keywords}

Polysiloxane, silicone, thiol-ene, nanohybrids, surface plasmon resonance, gold nanoparticles 


\section{Introduction}

In recent years, the interest in nanomaterials based on semiconductors or metals has considerably increased. At this scale, these materials have unique optical, electronic and catalytic properties which are used in many applications (low concentration detection of analytes,${ }^{[1-3]}$ catalysis, ${ }^{[4-6]}$ therapy, ${ }^{[7,8]}$ diagnosis, ${ }^{[9]}$ tissue engineering, ${ }^{[10]}$ high resolution imaging, ${ }^{[1]}$ electronics $\left.{ }^{[12]} \ldots\right)$. The use of these nanoparticles for a targeted application often requires modifying their surface by adding an organic or inorganic layer. ${ }^{[13-17]}$ This additional layer has two main advantages. First it enables the dispersion of nanohybrids in different solvents and improves their colloidal stability. Secondly it changes the nanohybrid properties and can provide a recognition function or a response to a stimulus.

The objective of this work is to study gold nanohybrids obtained by coating gold nanoparticles ("NP") with functionalized polysiloxanes. These nanohybrids can be characterized by their absorbance in the visible spectrum, linked to the Surface Plasmon Resonance (SPR) phenomenon. First, the SPR band of the gold NPs is expected to shift when the functionalized polysiloxane used to coat their surface is changed. Secondly, once coated, a change in the environment of the coated nanoparticle (solvent, chemicals....) may change the polysiloxane conformation and/or its interaction with the gold surface, resulting in an extra shift of the SPR band. As a result, the hybrid nanoparticle could be used as a sensor.

Polysiloxanes were selected because these polymers are very flexible, with a low glass transition temperature. Thus, they are expected to change their conformation quite easily in response to different stimuli (solvents, temperature, ions, sugars, proteins ...). In addition, the grafting of suitable organic groups can modulate their refractive index. ${ }^{[18,19]}$ The functionalization of polysiloxanes is not always easy because the siloxane bond is sensitive to acid or basic conditions. Few reactions are convenient for preserving the silicone polymer and notably the most used is hydrosilylation, but more recently, other strategies are developed such as azide-alkyne click chemistry, ${ }^{[20]}$ Schiff base chemistry, ${ }^{[21]}$ Piers-Rubinsztajn reaction, ${ }^{[22]}$ thioacetals, ${ }^{[23]}$ aza-Michael ${ }^{[24]}$...etc.... The thiol-ene reaction also appears as a suitable strategy for grafting in a single step various unprotected functional groups, including acids, amines or alcohols. Since the reaction is a radical reaction, it preserves well the integrity of the polysiloxane backbone. The reaction is initiated either thermally in the presence of a radical initiator or by photochemistry, preferentially in the presence of a photoinitiator. Finally, the precursor polymers, vinyl polysiloxanes, are easy to prepare with different proportions of vinyl functions distributed throughout the chain. This reaction ensures the distribution of the desired functions throughout the polysiloxane backbone (such as amides, phenyl, fluorinated), in addition to the thioether functions. The latters are expected to help the formation of nanohybrids through the interaction of the thioether with the gold surface. The thiol-ene reaction has been increasingly used in the last years for functionalizing polysiloxanes ${ }^{[25-31]}$. It has been used notably for preparing hydrophilic or amphiphilic polysiloxanes, ${ }^{[32-36]}$ surface functionalized PDMS elastomers, ${ }^{[37,38]}$ antibacterial silicones, ${ }^{[39]}$ elastomers for modulating cell adhesion, ${ }^{[40]}$ self-healing polysiloxanes, ${ }^{[41]}$ polysiloxanes elastomers with optical properties, ${ }^{[42,43]}$ liquid crystal polysiloxanes, ${ }^{[44]}$ electroactive ferrocene-grafted polysiloxanes, ${ }^{[45,46]}$ polysiloxanes with tunable dielectric properties, ${ }^{[4]}$ or contact lens elastomers. ${ }^{[48]}$ Thiol-ene strategy is also used in the case of polysiloxanes for getting an efficient, orthogonal cross-linking, ${ }^{[18,49-51]}$ often initiated photochemically and consequently, has been adapted to electrospinning ${ }^{[52]}$ and $3 \mathrm{D}$ printing. ${ }^{[53-55]}$ 
In this work, the functionalized polysiloxanes have been prepared in two steps: the first step consisted in preparing poly(methylvinyl-co-dimethyl)siloxanes containing around $25 \%$ of vinyl groups, by cationic redistribution (Figure 1). In the second step, three different thiols Nmethylmercaptoacetamide $\mathbf{4}$, phenylethanethiol $\mathbf{5}$ and $3,3,4,4,5,5,6,6,7,7,8,8,9,9,10,10,10$ heptadecafluoro-1-decanethiol 6 (Figure 1) were grafted by thiol-ene reaction on the vinyl polysiloxane. In addition to varying the refractive index surrounding the particles, the different grafts have different polarities and are prone to make varied molecular interactions (hydrogen bonds, hydrophobic interactions, $\pi-\pi$ stacking ...). N-Methyl-mercaptoacetamide 4 was also selected in order to introduce a relatively hydrophilic group able to provide strong hydrogen bonding and to impart solubility to the corresponding grafted polysiloxane in polar solvents, such as DMF or DMSO. Actually, such polysiloxanes soluble in DMF or DMSO are interesting for the preparation of carbohydrate grafted polysiloxanes ("glycosilicones"), since they would enable the direct grafting of unprotected carbohydrate moities in monophasic conditions. ${ }^{[56-58]}$

Concerning the gold nanoparticles, the wavelength of the Surface Plasmon resonance (SPR) absorption band is affected by many factors. ${ }^{[59,60]}$ It is mainly affected by the particle shape, ${ }^{[61]}$ dimensions and aggregation. Aggregation of gold nanoparticles produced a strong blue shift of the SPR band. It can be irreversible or reversible, depending on the system. ${ }^{[3,62]}$ This shift due to aggregation is typically used for biodetection, relying on antigen-antibody complexation or DNA hybridization that leads to aggregated gold nanoparticles. ${ }^{[59]}$ However, in our work, we were mostly interested in the subtle variations induced by the interactions of polymers with the gold nanoparticles in solution that do not provoke the aggregation and settling of nanoparticles. The wavelength shift is usually small compared to the shift due to aggregation, but can bring information on the surrounding of the nanoparticles. Accordingly, the SPR band is affected by the solvent refractive index, ${ }^{[63]}$ by organic layers, either well-organized monolayers, ${ }^{[64]}$ surfactants ${ }^{[65]}$ or polymers, ${ }^{[66-68]}$ wrapping the nanoparticle. When this organic layer is stimuliresponsive, the SPR band shifts with the application of the stimulus. Consequently, the nanoparticle suspension (but also single nanoparticles ${ }^{[69]}$ ) can behave as a sensor. Thus, the observation of a SPR band shift without aggregation phenomenon has been applied to the detection of ions and chemicals ${ }^{[70-73]}$ (including pesticides ${ }^{[74]}$ ) or biomolecules ${ }^{[61,75-82]}$. The detection of different chemicals at ultralow concentrations ${ }^{[83]}$ or single atomic ions ${ }^{[70]}$ has been demonstrated. This method of detection, which does not require labeling is known as "LSPR nanosensors" for "Localized Surface Plasmon Resonance Nanosensors" or localized surface plasmon resonance detection. ${ }^{[84-89]}$ The plasmon band shift is also more sensitive in the case of anisotropic or hollow (gold shells) ${ }^{[90]}$ nanoparticles and for this reason rod, branched or hollow nanoparticles are preferentially used for this purpose. ${ }^{[91]}$ In this work, we used a surfactant-free method, based on the reduction of the gold tetrachloroauric acid by glucosamine for generating branched gold nanoparticles. ${ }^{[92]}$ 


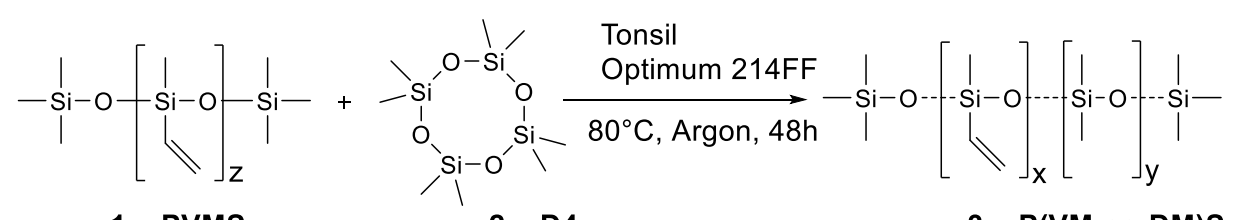

$1=$ PVMS $2=\mathrm{D4}$

$3=\mathbf{P}(\mathrm{VM}-$-co-DM $) \mathrm{S}$
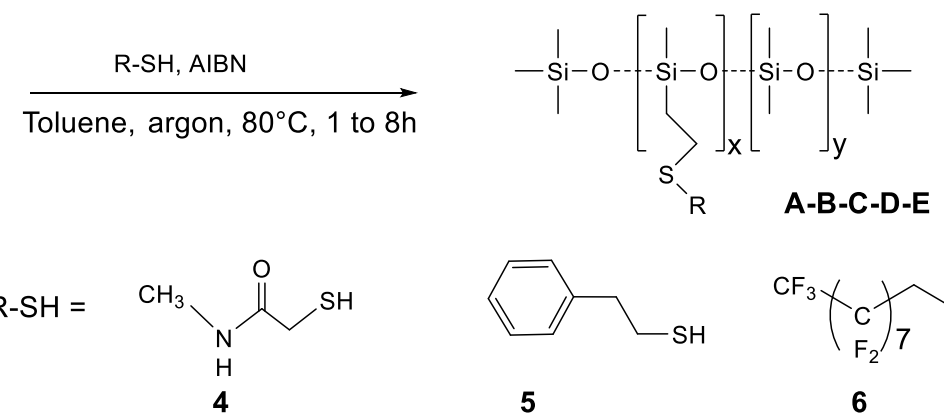

$\mathrm{CF}_{3} \times\left(\begin{array}{l}\mathrm{C} \\ \mathrm{F}_{2}\end{array} \mathrm{~T}_{7}^{\mathrm{SH}}\right.$

5

6

Figure 1: General scheme for the synthesis of functionalized polysiloxanes

A : P(AcM-co-DM)S

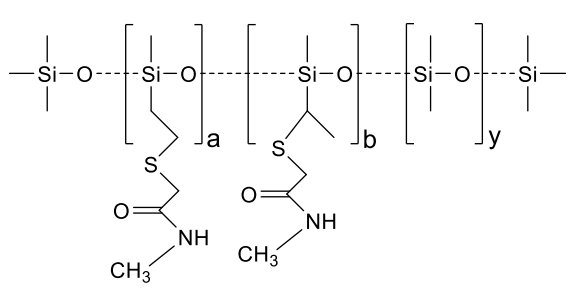

D : P(AcM-co-PhM-co-DM)S

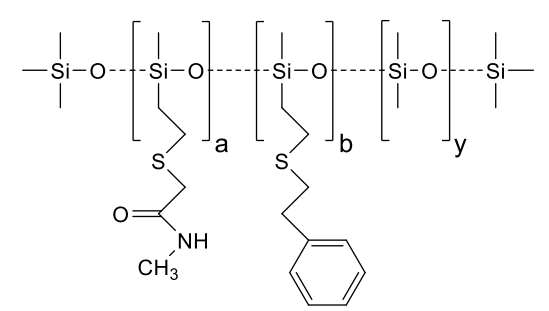

B : P(PhM-Co-DM)S

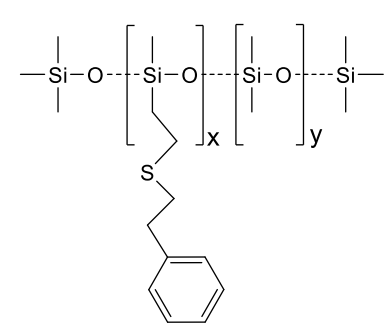

$E: P(A c M-c o-F M-c o-D M) S$

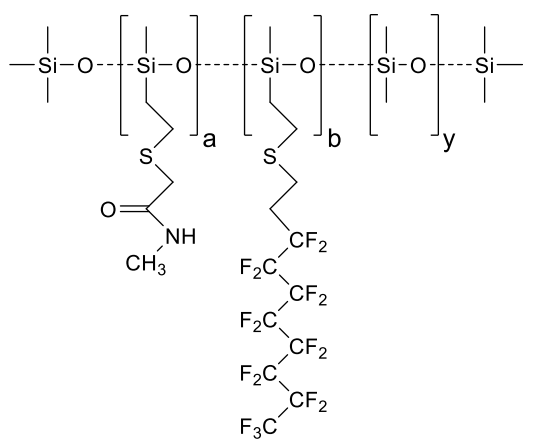

Figure 2 : Functionalized polysiloxanes prepared 


\section{Results and discussion}

\section{Synthesis of functionalized polydimethylsiloxanes}

In a first step, the copolymer 3 (poly(methylvinyl-co-dimethyl) siloxane or P(VM-co-DM)S was prepared by cationic redistribution of a polymethylvinylsiloxane $\mathbf{1}$ with about 16 units (PVMS, 1) with octamethyltetrasiloxane (2, D4), in the presence of an acid catalyst (Tonsil Optimum) (Figure 1). The redistribution was fully characterized by SEC, ${ }^{1} \mathrm{H}$ NMR, ${ }^{13} \mathrm{C}$ NMR and ${ }^{29} \mathrm{Si}$ NMR and led to the desired copolymer with a $\mathrm{Mn}$ around $5500 \mathrm{~g} / \mathrm{mol}$ and a methylvinylsiloxane unit ratio $=23 \%$ (the feeding ratio was 28\%). Assignment of the different triads and their respective integrals allowed to assess the quality of the redistribution of vinyl groups within the siloxane structure. Based on the triads centered on a D pattern, a distribution close to the one corresponding to a random statistical distribution is observed: the respective integrations ratio for the triads DDD, VDD/DDV and VDV were found equal to 66, 30 and 4\% close to the theoretical values of 59,36 and 5\% (where D stands for dimethylsiloxane unit and $\mathrm{V}$ for methylvinylsiloxane unit).

The P(VM-co-DM)S copolymer 3 was then functionalized by a thiol-ene reaction with three different thiols, N-methyl-mercaptoacetamide $\mathbf{4}, \quad$ 2-phenylethanethiol $\mathbf{5}, \quad$ and 3,3,4,4,5,5,6,6,7,7,8,8,9,9,10,10,10-heptadecafluoro-1-decanethiol $\mathbf{6}$ to give three copolymers: A: P(AcM-co-DM)S, B: P(PhM-co-DM)S, C: P(FM-co-DM)S and two terpolymers: D: $\mathrm{P}($ AcM-co-PhM-co-DM)S, F: P(AcM-co-FM-co-DM)S (Figure 2). In the case of terpolymers, the thiols were introduced in equimolar amounts, namely with $0.5 \mathrm{~mol}$ of thiol 4 and $0.5 \mathrm{~mol}$ of thiol $\{\mathbf{5}$ or $\mathbf{6}\}$ for $1 \mathrm{~mol}$ of vinyl. The reaction was performed under thermally activated radical conditions, by addition of azobisisobutyronitrile (AIBN), under inert atmosphere and heating for 8 hours at $80^{\circ} \mathrm{C}$. The polymers were purified by precipitation in cold acetonitrile. Characterization of the copolymers was made by ${ }^{1} \mathrm{H}$ NMR, ${ }^{13} \mathrm{C}$ NMR, ${ }^{29} \mathrm{Si}$ NMR and size exclusion chromatography (SEC) (SI-1 and SI-2). We focused on the conversion of the vinyl function and the grafting position of the thiol on this function (in $\alpha$ or $\beta$ position relative to the silicon atom). For the 2-phenylethanethiol $\mathbf{5}$ and for the fluorinated thiol $\mathbf{6}$, the reaction occurred at $100 \%$ on the carbon in $\beta$ of the silicon atom, but in the case of $\mathrm{N}$-methyl-mercaptoacetamide 4, $14 \%$ of the thiol-ene reaction occurred on the carbon in $\alpha$ of the silicon, which can be quantified by ${ }^{1} \mathrm{H}$ NMR (Figure 4 and SI-2). The results are reported in Table 1. The reaction was very efficient and $100 \%$ of the vinyl groups are converted to the thioethers for the 2phenylethanethiol, N-methyl-mercaptoacetamide, with no vinyl function visible in NMR after reaction. With the fluorinated thiol, the reaction was not complete, even by adding $20 \%$ mol of AIBN and 10 to $20 \%$ of unreacted vinyl groups are observed. This thiol would need further excess of AIBN for achieving a complete reaction. The thiol-ene reaction does not break the polysiloxane chain: the three polymers showed a peak in SEC with retention time and a shape quite similar to the starting polymer $\mathrm{P}(\mathrm{VM}-\mathrm{co}-\mathrm{DM}) \mathrm{S} \mathrm{3}$, without enlargement or shouldering of the peak (Figure 3 and SI-1). Overall, except the issue of bad smelling of the reagents, this reaction is easy to implement compared to hydrosilylation or click chemistry and very respectful of the silicone backbone. Concerning their visual aspect and solubility, P(FM-coDM)S C exhibits a slight iridescence under light illumination and the other three polymers (P(VM-co-DM)S 3, P(AcM-co-DM)S A and $\mathrm{P}(\mathrm{PhM}-\mathrm{co}-\mathrm{DM}) \mathrm{S}) \mathbf{B}$ are transparent viscous liquids. These polymers are all soluble in $\mathrm{CHCl}_{3}$ and interestingly, $\mathrm{P}(\mathrm{AcM}-\mathrm{M}-\mathrm{DM}) \mathrm{S} \mathbf{A}$ is soluble in DMF and DMSO and P(FM-co-DM)S C is slightly soluble in DMF. 

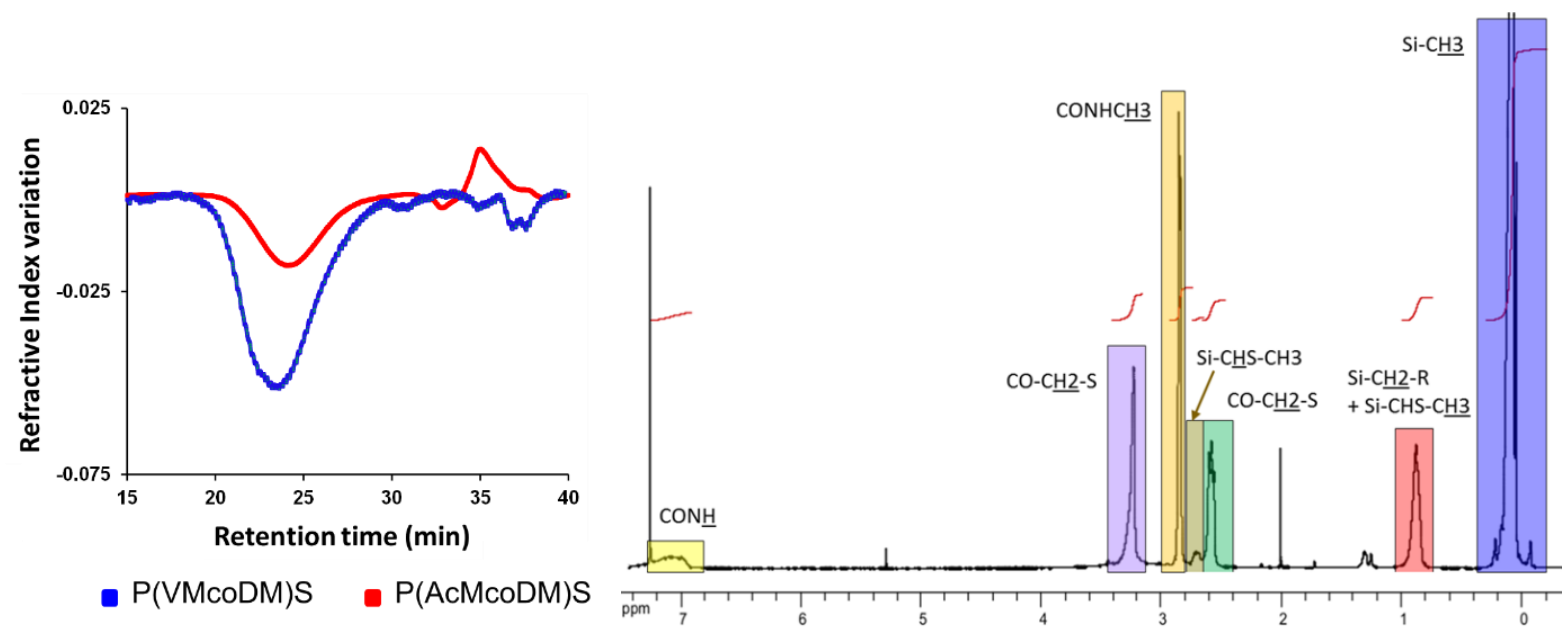

Figure 3: Left: Size Exclusion Chromatogram of $\mathrm{P}(\mathrm{AcM}-\mathrm{co}-\mathrm{DM}) \mathrm{S}$ A after thiol-ene reaction of $\mathrm{P}(\mathrm{Vm}-$ co-DM)S 3 with with N-methyl-mercaptoacetamide 4. Right: ${ }^{1} \mathrm{H}$ NMR spectrum of P(AcM-co-DM)S $\mathrm{A}$ in $\mathrm{CDCl}_{3}$.

Table 1: Polymers properties and SPR maximum and shift for branched gold nanoparticles polysiloxane hybrids

\begin{tabular}{|c|c|c|c|c|c|c|c|c|c|c|c|}
\hline Polymer & $\begin{array}{c}\mathrm{n}_{20} \mathrm{D} \\
{[\mathrm{a}]}\end{array}$ & $\begin{array}{l}\text { Solubility } \\
\text { In DMF }\end{array}$ & Yield & $\begin{array}{c}\text { Vinyl } \\
\text { conversion }\end{array}$ & $\begin{array}{c}\text { grafting } \\
\text { in alpha } \\
(\%)\end{array}$ & $\begin{array}{c}\text { SEC } \\
\text { RT } \\
\left(\min _{[b]}\right)\end{array}$ & $\begin{array}{c}\text { Mn } \\
\text { meas. } \\
\text { (calc.) } \\
\text { [c] }\end{array}$ & $\mathrm{Mw}$ & $\begin{array}{l}\text { IP } \\
\text { [d] }\end{array}$ & $\begin{array}{l}\text { SPR max } \\
\text { (SPR } \\
\text { shift) } \\
\text { (nm) } \\
\text { spherical } \\
\text { [e] }\end{array}$ & $\begin{array}{l}\text { SPR max } \\
\text { (SPR } \\
\text { shift) } \\
(\mathrm{nm}) \\
\text { branched } \\
{[\mathrm{f}]}\end{array}$ \\
\hline 3 & $\begin{array}{l}1.43 \\
{\left[\mathrm{a}^{*}\right]}\end{array}$ & no & 72 & n.a. & n.a. & 25 & 5440 & 8360 & 1,5 & $\begin{array}{l}515 \\
(-2)\end{array}$ & $\begin{array}{c}695 \\
(+15)\end{array}$ \\
\hline A & 1.52 & yes & 71 & 100 & 14 & 24 & (7150) & - & - & $\begin{array}{l}513 \\
(-4)\end{array}$ & $\begin{array}{c}665 \\
(-15)\end{array}$ \\
\hline B & 1.58 & no & 95 & 100 & 0 & 23 & (7690) & - & - & $\begin{array}{c}519 \\
(+2)\end{array}$ & $\begin{array}{c}745 \\
(+65)\end{array}$ \\
\hline $\mathrm{C}$ & 1.31 & sparingly & 43 & 80 & 0 & 22 & $\begin{array}{c}5330 \\
(11700)\end{array}$ & 5660 & 1,1 & $\begin{array}{l}513 \\
(-4)\end{array}$ & $\begin{array}{c}665 \\
(-15)\end{array}$ \\
\hline
\end{tabular}

${ }^{[a]}$ refractive index of the thiols used for grafting and of poly(methylvinyl-co-dimethyl)siloxane [a*]. Refractive index of a poly (dimethyl siloxane): 1.40 . Water $\left(20^{\circ} \mathrm{C}\right)=1.33$.

${ }^{\text {[b] }} \mathrm{SEC} \mathrm{RT}=$ retention time of the polymer by Size Exclusion Chromatrography

${ }^{[c]}$ For $\mathrm{P}(\mathrm{PhMcoDM}) \mathbf{B}$ and $\mathrm{P}(\mathrm{AcMcoDM}) \mathbf{A}$ the $\mathrm{dn} / \mathrm{dc}$ and the signal with the light scattering detector are too low to enable a correct determination of $\mathrm{Mn}$ and $\mathrm{Mw}$ by this method (Mn measured). The integrity of the polysiloxane is attested by the retention time and the shape of the peak. Mn can be calculated (Mn calc.) from Mn of $\mathrm{P}(\mathrm{VMcoDM}) 3$ on which the mass of the grafted thiol is added (23\% grafting).

${ }^{[d]} \mathrm{IP}=$ index of polydispersity

${ }^{[e]}$ shift of maximum wavelength of surface plasmon resonance band (SPR) compared to the "nude" spherical gold nanoparticles (517 nm is the maximum for the nude branched nanoparticles).

[f] shift of maximum wavelength of surface plasmon resonance band (SPR) compared to the "nude" branched gold nanoparticles (680 nm is the maximum for the nude branched nanoparticles). 


\section{Preparation of gold nanoparticles}

Two kinds of gold nanoparticles were synthesized. Nanoparticles with a spherical shape were synthesized by reduction of $\mathrm{HAuCl}_{4}$ by $\mathrm{NaBH}_{4}$. Experimental conditions were set to get these negatively charged nanoparticles with an average radius of approximately $5 \pm 2 \mathrm{~nm}$ (Figure $4 \mathrm{a}$ ). The gold nanoparticles stabilized by negative charges are sensitive to any increase of the ionic strength or change in $\mathrm{pH}$ which induces a charge neutralization and then aggregation. The preparation of branched gold nanoparticles ("nanostars") is based on the reduction of $\mathrm{HAuCl}_{4}$ by glucosamine $\cdot \mathrm{HCl}$ and $\mathrm{NaOH}$ as the unique reagents. Figure 5a shows the transmission electronic microscopy (TEM) images of gold nanostars obtained by this method, showing homogeneous morphologies and sizes. Nanoparticles with an overall diameter between 100 and $150 \mathrm{~nm}$ were obtained in high yield. The absorbance spectrum (Figure 5b) exhibit two surface plasmon resonance (SPR) bands. The first band around $540 \mathrm{~nm}$ is associated with the inner core $(540 \mathrm{~nm})$, while the second band around $680 \mathrm{~nm}$ could be attributed to the plasmon modes of the branches of the nanostars. These two families of nanoparticles have a high colloidal stability in aqueous solutions: hydrodynamic diameter $D_{h}$ equal to $10 \mathrm{~nm}$ (spherical) and $150 \mathrm{~nm}$ (branched) are measured and absorption spectra do not evolve significantly over a week period. Both results are compatible with well dispersed, not aggregated nanoparticles.

(a)

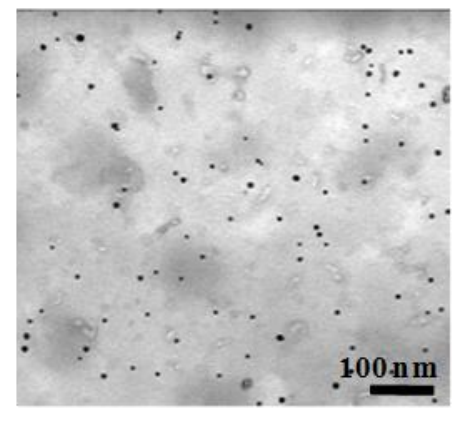

(b)

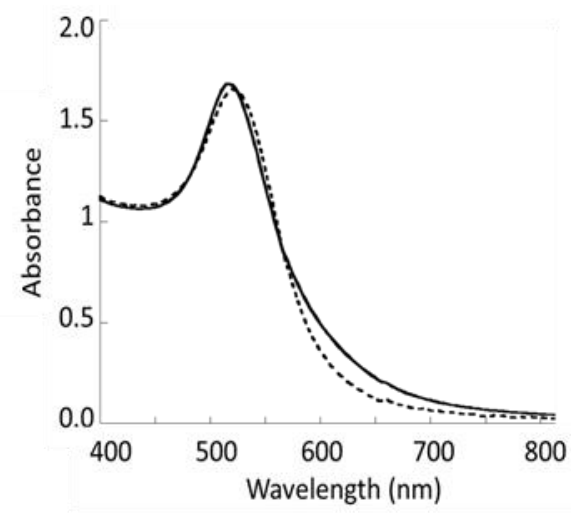

Figure 4. (a) TEM image and (b) UV-vis spectra of colloidal dispersions of spherical gold nanoparticles (mean diameter equal to $5 \pm 1 \mathrm{~nm}$ ) after 1 hour (solid line) and 1 month (dash line).

(a)

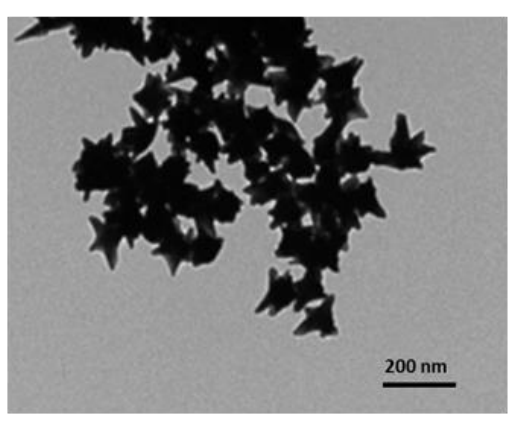

(b)

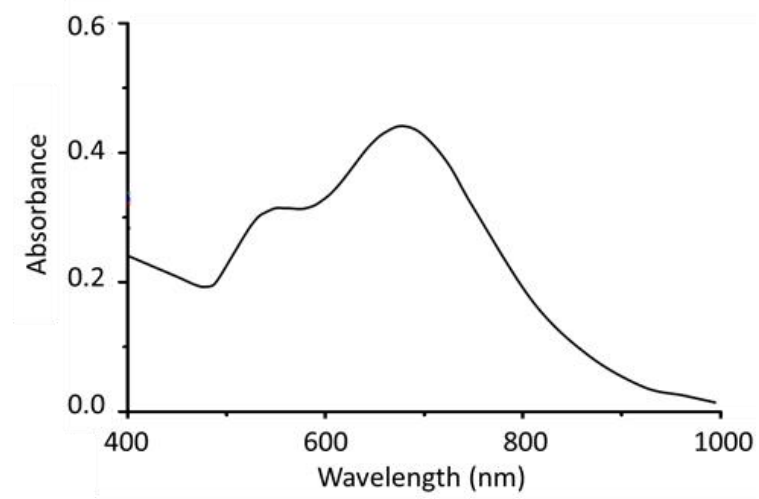

Figure 5. (a) TEM image and (b) UV-vis spectrum of colloidal dispersions of branched gold nanoparticles (diameters around 100-150 nm) 
The modified polysiloxanes were mixed with spherical and branched nanoparticles in order to evaluate their ability to interact with the surface of pristine gold nanoparticles and to modify surface plasmon band. Accordingly, a solution of spherical or branched gold nanoparticles was poured into glass tubes covered with a dried thin film of polymer. After stirring the nanoparticles coated with the polymer are obtained. The amount of polymer and of gold nanoparticles were adjusted at a quite low level to avoid aggregation. The optical properties of the resulting nanohybrids were then further studied (Figure 6).

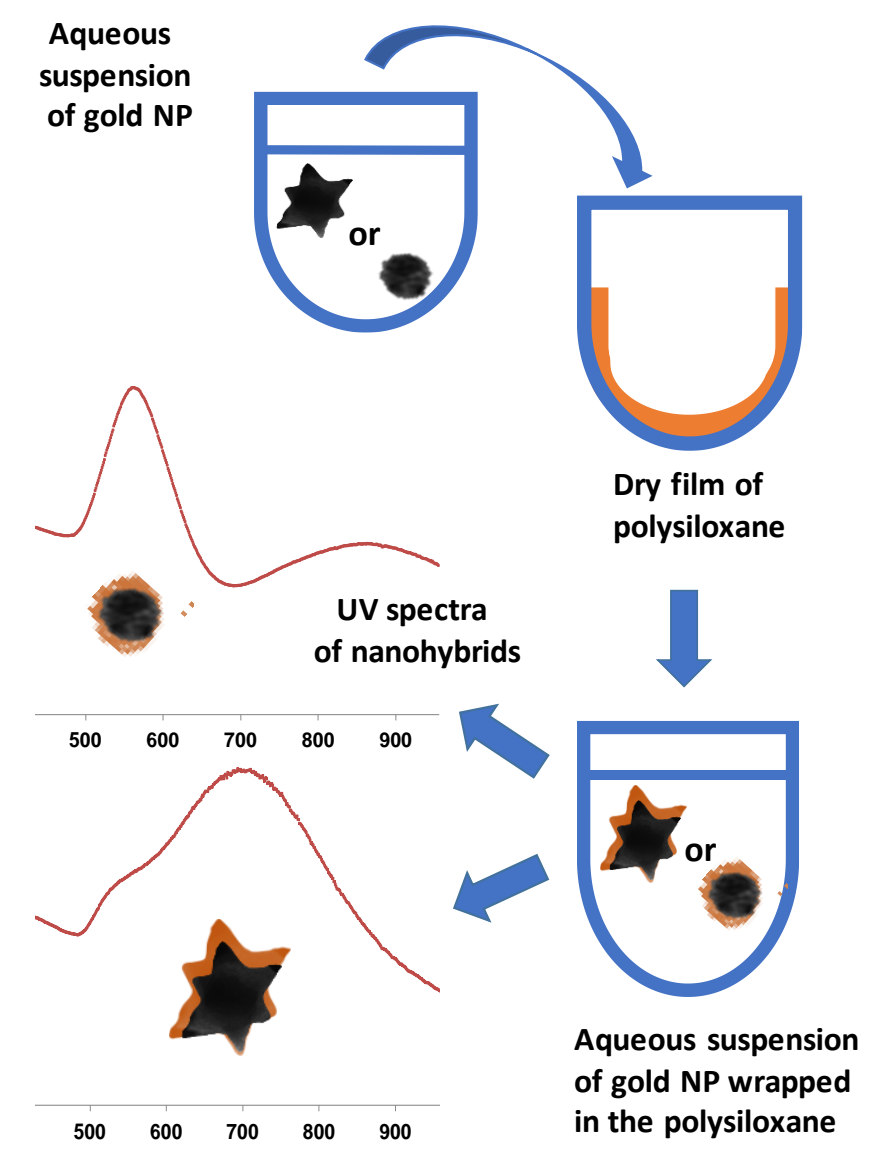

Figure 6 : Preparation of spherical or branched gold nanoparticles coated with a functionalized polysiloxane

In the case of spherical nanoparticles, the wrapping with the functionalized polysiloxane does not affect much the plasmon resonance band (Figure 7 and Table 1). A very slight red shift and intensity increase is observed with the $\mathrm{P}(\mathrm{PhM}-\mathrm{co}-\mathrm{DM}) \mathrm{S} \mathbf{B}(+2 \mathrm{~nm})$ and very slight blue shift is observed with P(FM-co-DM)S C (-4 nm), P(AcM-co-DM)S A (-4 nm) and P(VM-Co-DM)S 3 $(-2 \mathrm{~nm})$ (Table 1). Conversely, in the case of branched nanoparticles, significant shifts have been observed depending on the groups grafted on the polysiloxane (Figure 8 and Table 1). Compared to the "nude" branched nanoparticles only stabilized with glucosamine (SPR max $=$ 
$680 \mathrm{~nm}$ ), a slight red shift of $+15 \mathrm{~nm}$ is observed with P(VM-co-DM)S 3 (SPR max $=695$ ), while a strong red shift of $+65 \mathrm{~nm}$ and a higher absorbance is observed when the particles are wrapped with $\mathrm{P}(\mathrm{PhM}-\mathrm{co}-\mathrm{DM}) \mathrm{S} \mathbf{B}(\mathrm{SPR} \max =745 \mathrm{~nm})$. For the two more polar polysiloxanes A and C, a slight blue shift is observed of $-15 \mathrm{~nm}(\mathrm{SPR} \max =665 \mathrm{~nm})$, with a broadening of the bands and change in the relative intensity of the core vs branches SPR bands.

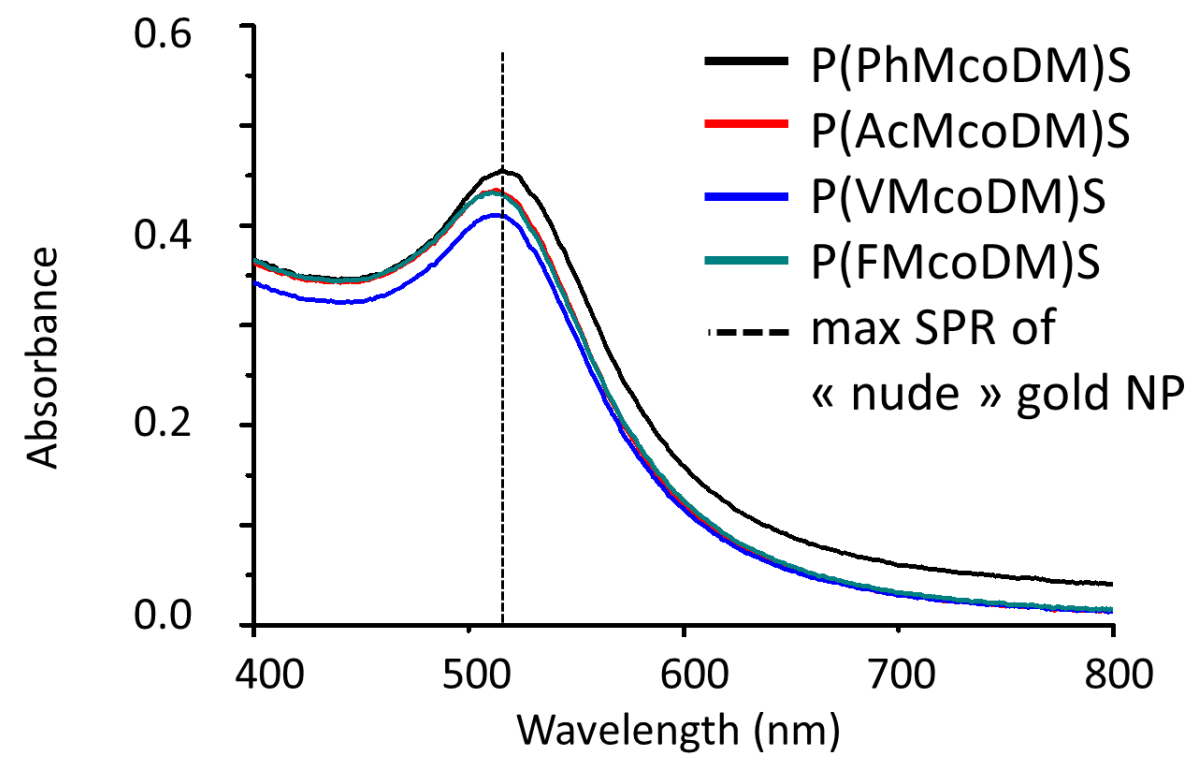

Figure 7. UV-vis spectrum of colloidal dispersions of spherical gold nanoparticles wrapped with polysiloxanes $\mathrm{P}(\mathrm{VM}-\mathrm{co}-\mathrm{DM}) \mathrm{S} \mathbf{3}, \mathrm{P}(\mathrm{AcM}$-co-DM $) \mathrm{S} \mathbf{A}, \mathrm{P}(\mathrm{PhM}-\mathrm{co-DM}) \mathrm{S}$ B and $\mathrm{P}(\mathrm{FM}-\mathrm{co}-$ $\mathrm{DM}) \mathrm{S} \mathbf{C}$ with different grafting

Therefore, adsorption of the different polymers on the surface of nanoparticles is evidenced by the modification of surface plasmon resonance position. This adsorption might be favored by the thioether function present on these polymers in addition to other specific functions and by the flexibility of siloxane chains. The observed effects on the SPR band followed the same trends with both spherical and branched NPs with a position of the maximum of SPR ranked as follow: phenyl $>$ vinyl $>$ acetamide $\approx$ fluorinated. This effect is, as expected, far more pronounced in the case of branched nanoparticles since anisotropic nanoparticles are known to be more sensitive to external factors. The observed effect can be ascribed to two phenomena. The first effect, as mentioned in the introduction, is related to the change of the refractive index of the surrounding layer of the nanoparticle, following the adsorption of a polymer layer on its surface $^{[63]}$. This is in quite good agreement with the expected change of refractive index of the grafted thiols that are ranked as follows: phenylethanethiol 5 (1.58) > N-methylmercaptoacetamide 4 (1.52) > poly(methylvinyl-co-dimethyl)siloxane (1.43) > heptadecafluoro-1-decanethiol 6 (1.31) (see Table 1). Nevertheless, the observed effect could not be solely ascribed to this modification of refractive index, notably because P(VM-co-DM)S 3 and $\mathrm{P}(\mathrm{AcM}-\mathrm{co}-\mathrm{DM}) \mathrm{S} \mathbf{A}$ do not strictly follow the refractive index ranking. In fact, the silicone backbone also can play a role on the mean refractive index of the polysiloxane, that should be close to the poly(methylvinyl-co-dimethyl)siloxane refractive index (1.43). It represents more or less $75 \%$ of the polymer and thus could hide in part the effect of the side groups. Also, among the polymers studied, two of them are hydrophobic P(VM-Co-DM)S 3 and $\mathrm{P}(\mathrm{PhM}-\mathrm{Co}-\mathrm{DM}) \mathrm{S}$ $\mathbf{B}$ and two of them are more polar P(AcM-Co-DM)S A and P(FM-Co-DM)S C. The precise conformation of the polymer at the gold /water interface might modulate both the shift and the intensity of the SPR band. In the case of hydrophobic polymers, an increase of the polymer 
concentration lead to aggregation of the nanohybrids and their irreversible precipitation as inferred from DLS measurements by the significant increase of measured hydrodynamic diameter. To minimize this phenomenon, a very low concentration of polymer equal to $1.6 .10^{-}$ ${ }^{6}$ wt.\% for all polymers was used. This concentration ensures good colloidal stability of the generated nanohybrids and no significant change of measured absorption spectra and hydrodynamic diameter of the formed nanohybrid was observed over a few days. However, the hydrophobic character of the polymer may favor aggregation phenomenon that could explain in part the blue shift in the case of $\mathrm{P}(\mathrm{VM}-\mathrm{co}-\mathrm{DM}) \mathrm{S} \mathbf{3}$ and $\mathrm{P}(\mathrm{PhM}-\mathrm{co}-\mathrm{DM}) \mathrm{S} \mathbf{B}$, in addition to the refractive index effect. For the two more polar polymers, the enlargement of the SPR band and the change of the relative intensity of the core vs branches band could also revealed colloidal interactions, but in this case, related to hydrogen bonding, amphiphilic behavior or dipolar interactions. Mix between these different effects can finally explained the SPR shifts observed.

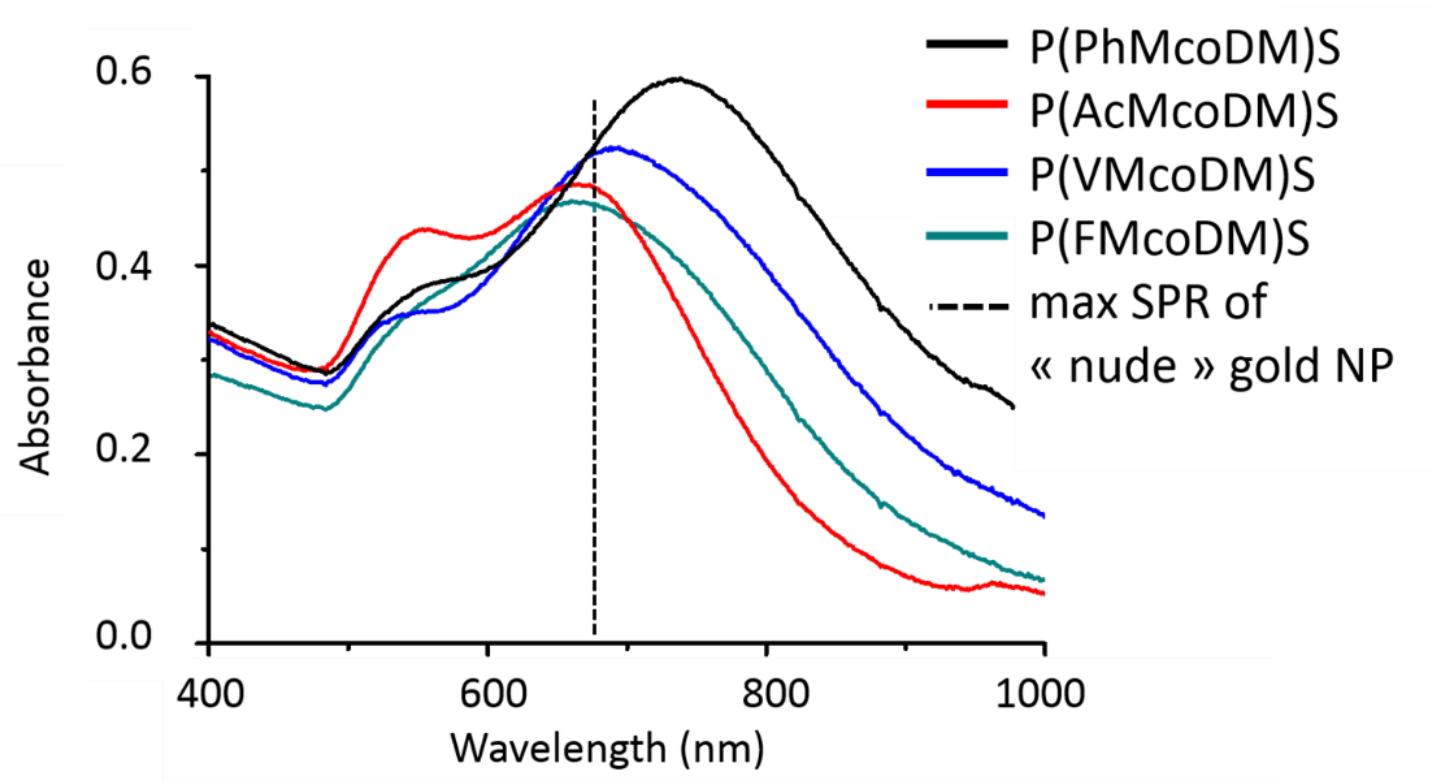

Figure 8. UV-vis spectrum of colloidal dispersions of branched gold nanoparticles wrapped with polysiloxanes $\mathrm{P}(\mathrm{VM}-\mathrm{co-DM}) \mathrm{S} \mathrm{3,} \mathrm{P(AcM-co-DM)S} \mathrm{A,} \mathrm{P(PhM-co-DM)S} \mathrm{B} \mathrm{and} \mathrm{P(FM-co-DM)S}$ C with different grafting

\section{Conclusion}

The functionalization of polysiloxanes by thiol-ene reaction appears as a very efficient route, complete, with good yields and respectful of the polysiloxane backbone. It also tends to be easier to implement than hydrosilylation. This method is thus increasingly used in recent years to prepare functionalized polysiloxanes and also as a cross-linking method. It also enables the easy introduction of polar groups, giving polysiloxanes sufficiently hydrophilic to make them soluble in polar solvents, thus opening the way for introducing polar groups such as unprotected carbohydrates. The wrapping of gold nanoparticles with the grafted polysiloxanes leads to a shift of the surface plasmon resonance band. It can be related in part to the relative refractive index of the polysiloxanes and may be affected also by possible polymer-polymer interactions depending on the polar or apolar character of the polymers. 


\section{Experimental section}

Materials: Tetrachloroauric acid trihydrate $\left(\mathrm{HAuCl}_{4}, 3 \mathrm{H}_{2} \mathrm{O}\right)$, sodium borohydride $\left(\mathrm{NaBH}_{4}\right)$, glucosamine $\cdot \mathrm{HCl}$ and sodium hydroxide $(\mathrm{NaOH})$ were purchased from Aldrich Fine chemicals and were used without further purification. Azobisisobutyronitrile (AIBN) is purchased from Aldrich Fine chemicals and recrystallized from ethanol before use. PolyVinylMethylSiloxane and Tonsil Optimum 214FF® were obtained from Gelest and Süd Chemie respectively. Absolute ethanol (AnalaR normapur VWR) was used as received. Using a Purite device, water was purified through a filter and ion exchange resin (resistivity $\approx 18 \mathrm{M} \Omega . \mathrm{cm}$ ). All glassware and magnetic stir bar should be washed with aqua regia. In order to ensure the proper cleaning of the utensils and containers, they are systematically washed using first aqua regia, then three rinses with ultrapure water, acetone and finally ethanol before drying. For all reactions performed with thiols, the glassware, reaction residues and accessories were washed after reaction and after recovering the desired product in a bath of sodium hypochlorite aqueous solution before being discarded in order to oxidize the unreacted thiols.

Characterization: Size Exclusion Chromatography has been performed on coupled Ultrastyragel columns HR1, HR3 and HR4 (Waters) at a flow rate of $1 \mathrm{ml} / \mathrm{min}$ at $35^{\circ} \mathrm{C}$ in toluene. A refractive index (RI) detector Optilab Wyatt and a static light scattering (SLS) detector Mini-Dawn Wyatt were used as detector. Refractive index increments $\mathrm{dn} / \mathrm{dC}$ have been measured in toluene with DnDc-2010 apparatus from Polymer Standards Service. ${ }^{1} \mathrm{H}$ NMR and ${ }^{29} \mathrm{Si}$ NMR has been performed on Brucker Advance $300 \mathrm{MHz}$ and on Brucker Advance 400 $\mathrm{MHz}$ spectrometers respectively. ${ }^{13} \mathrm{C}$ NMR and correlation experiments have been performed on a Brucker Advance $500 \mathrm{MHz}$.

Dynamic Light Scattering (DLS) and zeta potential measurements were carried out at $25^{\circ} \mathrm{C}$ with a Malvern Instrument Nano-ZS equipped with a He-Ne laser $(\lambda=633 \mathrm{~nm})$. Samples were introduced into cells (pathway: $10 \mathrm{~mm}$ ) after filtration through $0.45 \mu \mathrm{m}$ PTFE micro-filters. The correlation function was analyzed via the non negative least square (NNLS) algorithm to obtain the distribution of diffusion coefficients (D) of the solutes, and then the apparent equivalent hydrodynamic diameter $(\langle\mathrm{Dh}\rangle)$ was determined using the Stokes-Einstein equation. Mean diameter values were obtained from three different runs. Standard deviations were evaluated from diameter distribution and was equal to $5 \mathrm{~nm}$ for all samples. For Zeta potential measurements, zeta potential was extracted from mobility values using Smoluchowski model. Transmission Electron Microscopy (TEM). A drop of the aqueous dispersions was placed on a carbon-coated copper TEM grid and left to dry under air. For samples needing negative staining, the TEM grids were successively placed on a drop of the sample solution for 2 min, on a drop of an aqueous solution of uranyl acetate (2 wt.\%, $2 \mathrm{~min}$ ) and finally on a drop of distilled water, after which the grids were then air-dried before introduction into the electron microscope. The samples were observed with a HITACHI HU12 microscope operating at 70 $\mathrm{kV}$. Size distribution was determined by manual counting on ca. 150 particles, using WCIF Image J software. UV-visible spectroscopy measurements. An Analytik Jena diode array spectrometer (Specord 600) or a BMG Labtech diode array spectrometer (Spectrostar nano) equipped with a temperature control system was used for UV-visible absorption spectra recording (optical path length: $1 \mathrm{~cm}$ ). 
Preparation of poly (methylvinyl-co-dimethyl) siloxane, P(VM-co-DM)S 3.

Redistribution of PVMS with D4.

In a reactor equipped with a magnetic stirrer, introduce $222 \mathrm{mg}$ ( $2 \%$ by weight relative to the mixture) of Tonsil Optimum 214FF® (Süd Chemie) catalyst under an inert atmosphere. Introduce $100 \mathrm{mmol}$ of anhydrous D4 2 (octamethylcyclotetrasiloxane), ie a mass of $7.4 \mathrm{~g}$ and $67 \mathrm{mmol}$ of linear PVMS 1 (PolyVinylMethylSiloxane, Gelest) or a mass of $3.68 \mathrm{~g}$. Heat for 23 to 48 hours at $75-80^{\circ} \mathrm{C}$ with gentle stirring and under an inert atmosphere. The polymer solution is diluted in hexane and then filtered on a sintered filter cone in the presence of decalite ${ }^{\circledR}$. Finally, the filtrate is passed through a $0.2 \mu \mathrm{m}$ PTFE filter to remove any trace of catalyst. The solution thus obtained is concentrated in vacuo, and the polymer is then precipitated by adding dropwise the filtered solution in a solution of methanol at $4^{\circ} \mathrm{C}$. After removing the supernatant, the precipitate is dried under vacuum at $100^{\circ} \mathrm{C}$ with stirring for three hours. This last step makes it possible to eliminate small cycles and short chains. SEC: retention time $(\mathrm{RI}$ detector $)=22.5 \mathrm{~min} . \mathrm{dn} / \mathrm{dc}=-0.091$. Ratio VM/DM (vinylmethylsiloxane / dimethylsiloxane units) $=23 \%$. Yield: $72 \%$.

NMR ${ }^{1} \mathrm{H}\left(\mathrm{CDCl}_{3}\right): \delta$ ppm: 5.90-6.06; 5.74-5.84 (2m, $\left.\mathrm{C} \underline{\mathrm{H}}=\mathrm{C}_{2}, 3 \mathrm{H}\right) ; 0.13-0.20 ; 0.02-0.13(2 \mathrm{~m}$, $\left.\mathrm{CH}_{3}-\mathrm{Si}, 22 \mathrm{H}\right) . \mathrm{NMR}^{29} \mathrm{Si}\left(\mathrm{CDCl}_{3}+0.03 \mathrm{M} \mathrm{Cr}(\mathrm{acac})_{3}\right): 2$ triads for $\mathrm{D}=\left[\left(\mathrm{CH}_{3}\right)_{2}-\mathrm{Si}-\mathrm{O}\right]$ and $\mathrm{V}=\left[\left(\mathrm{CH}_{3}\right)\left(\mathrm{CH}=\mathrm{CH}_{2}\right)-\mathrm{Si}-\mathrm{O}-\right], 1$ diad for $\mathrm{M}=\left[\left(\mathrm{CH}_{3}\right)_{3}-\mathrm{Si}-\mathrm{O}\right]: \delta_{\mathrm{ppm}}: 7.20-7.30(\mathrm{~m}, \underline{\mathrm{MDD}}, 0.11 \mathrm{Si})$; 7.32-7.40 (m, MDV, 0.04Si); 8.22-8.28 (m, $\underline{\mathrm{MVD}}$, 0.01Si); 8.35-8.40 (m, $\underline{\mathrm{MVV}}, 0.007 \mathrm{Si})$; 22.10 to -21.70 (m, DDD, 12.7Si); -21.60 to -21.20 (m, DDV and VDD, 5.6Si); -21.10 to -20.70

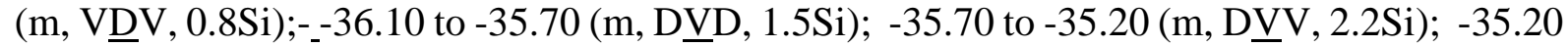
to -34.80 (m, VV V, 1.8Si). Detail for sub-triads. Triads centered on "D": -21.93 (m, DDDDD); -21.85 (m, DDDDV); -21.46 (m, DDDVD); -21.38 (m, DDDVV); -21.31 (m, VDDVV); 20.97 (m, DVDVD); -20.89 (m, DVㅁV). Triads centered on "V": -35,88 (m, DDVDD); -

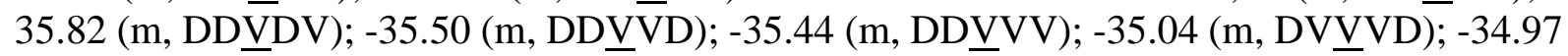
(m, DVVVV). $\mathrm{NMR}{ }^{13} \mathrm{C}\left(\mathrm{CDCl}_{3}\right): \bar{\delta}_{\mathrm{ppm}}: 137.5$ to $136.9\left(\mathrm{Si}-\underline{\mathrm{CH}}=\mathrm{CH}_{2}\right) ; 133.6$ to 132.8 (Si$\left.\mathrm{CH}=\underline{\mathrm{CH}}_{2}\right) 2.1 ; 1.8-0.9 ; 0.3\left(\mathrm{Si}-\mathrm{CH}_{3}\right)$. Signals from 137.5 to $136.9\left(\mathrm{Si}-\underline{\mathrm{CH}}=\mathrm{CH}_{2}\right)$ and from 133.6 to $132.8\left(\mathrm{Si}-\mathrm{CH}=\mathrm{CH}_{2}\right)$ come out very clearly in the form of triads, which must be attributable to the influence neighboring patterns ( $\mathrm{D}$ or $\mathrm{V}$ ). The attribution could not be made with certainty and would require a coupling study with silicon. The integrations and forms of the signals, however, make it possible to make the following attribution hypothesis: triad $\mathrm{Si}-\underline{\mathrm{CH}}=\mathrm{CH}_{2}$ : 137.5-137.3 (m, VVV); 137.3-137.1 (m, DVV, VVD); 136.9-137.1 (m, DVD)); triad Si$\mathrm{CH}=\underline{\mathrm{CH}}_{2}$ : 133.6-133.3 (m, DVD); 133.3-133.2 (m, DVV, VVD); 132.8-133.2 (m, VVV).

\section{General protocol of the thiol-ene reaction on $\mathrm{P}(\mathrm{VM}-\mathrm{Co}-\mathrm{DM}) \mathrm{S} 3$}

In a reactor equipped with a magnetic stirrer, $1 \mathrm{~g}$ of $\mathrm{P}(\mathrm{VM}-\mathrm{Co}-\mathrm{DM}) \mathrm{S} \mathbf{3}$ with $23 \%$ of vinyl functions, ( $3 \mathrm{mmol}$ of vinyl functions) is introduced. 1.7 eq./vinyl of thiol reagent is introduced $(5 \mathrm{mmol})$ are introduced. In the case of thiol-ene reactions involving two thiol reactants (heterofunctionalization), an equimolar proportion is used, rather than an excess, so as to introduce the two thiols in an equivalent way. Azobisisobutyronitrile (AIBN) is then added in a proportion from $2 \%$ to $20 \mathrm{~mol} \%$ relative to the thiol introduced, ie approximately 0.05 to 0.7 mmol. The amount was adjusted according to the nature of the thiol and the efficiency of the reaction. The whole is diluted in $4 \mathrm{~mL}$ of toluene and then deoxygenated by argon bubbling for at least 30 minutes, and then maintained under an inert atmosphere throughout the duration of the reaction. Heat for 1 hours at $80^{\circ} \mathrm{C}$ with relatively rapid stirring. The reaction is stopped by 
stopping the heating. Evaporate the solvent on the rotary evaporator and then on the vacuum manifold for a limited time to prevent loss of the product by evaporation. The reaction product is purified by precipitation. Precipitation conditions were adjusted according to the nature of the polymer. The following thiols employed without prior purification: Nmethylmercaptoacetamide $\mathbf{4}$, 2-phenylethanethiol $\mathbf{5}, \quad 3,3,4,4,5,5,6,6,7,7,8,8,9,9,10,10,10$ heptadecafluoro-1-decanethiol 6. AIBN = Azo-bis-isobutyronitrile.

\section{A: Poly (methyl-N-methylaminocarbonylmethylthioethyl-co-dimethyl) siloxane, P(AcM- co-DM)S}

For the reaction with $\mathrm{N}$-methyl-mercaptoacetamide 4, $440 \mu \mathrm{L}$ of thiol are introduced (5 mmol) with $1.0 \mathrm{~g}$ of P(VM-co-DM)S 3 (13 mmol, $3 \mathrm{mmol}$ of vinyl groups), and $90 \mathrm{mg}$ AIBN (0.5 $\mathrm{mmol}, 10 \% \mathrm{~mol} /$ thiol) in $4 \mathrm{~mL}$ toluene. The polymer is purified by precipitation in cold acetonitrile. The crude product is added dropwise into acetonitrile at $-20^{\circ} \mathrm{C}$ and left at $-20^{\circ} \mathrm{C}$ for $3 \mathrm{~h}$. This operation is repeated three times, each time removing the acetonitrile. The polymer is precipitated at the bottom of the flask. After drying, a transparent pale yellow viscous liquid is obtained. SEC: retention time (RI detector) $=24 \mathrm{~min}$.

$\mathrm{dn} / \mathrm{dc}=-0,06$. Yield: $71 \%$.

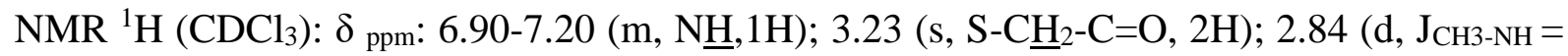
4.8, $\underline{\mathrm{CH}}_{3}-\mathrm{NHCO}, 3 \mathrm{H}$ ); $2.75-2.85$ (m, Si-CH${ }_{2}-\underline{\mathrm{C}}_{2}-\mathrm{S}, 0.14 \mathrm{H}$ ), 2.50-2.62 (m, Si-CH${ }_{2}-\underline{\mathrm{C}}_{2}-\mathrm{S}$, $1.72 \mathrm{H}) ; 0.80-1.00$ (m, Si-C $\left.\underline{\mathrm{H}}_{2}-\mathrm{CH}_{2}-\mathrm{S}, 2 \mathrm{H}\right) ; 0.00-0.20$ (m, $\left.\underline{\mathrm{H}}_{3} \mathrm{C}-\mathrm{Si}, 20 \mathrm{H}\right) . \mathrm{NMR}^{29} \mathrm{Si}\left(\mathrm{CDCl}_{3}+\right.$ $\left.0.03 \mathrm{M} \mathrm{Cr}(\mathrm{acac})_{3}\right): \delta_{\mathrm{ppm}}:-20$ to $-23\left(\mathrm{~m}, \mathrm{Si}\left(\mathrm{CH}_{3}\right)_{2}, 2 \mathrm{Si}\right) ;-23$ to $-26\left(\mathrm{~m}, \mathrm{SiCH}_{3}\left(\mathrm{CH}_{2}-\mathrm{CH}_{2}-\mathrm{S}-\right), 1 \mathrm{Si}\right)$. $\mathrm{NMR}{ }^{13} \mathrm{C}\left(\mathrm{CDCl}_{3}\right): \delta_{\mathrm{ppm}}: 170(\underline{\mathrm{CO}}) ; 36.3\left(\mathrm{~S}-\underline{\mathrm{CH}_{2}}-\mathrm{CO}\right) ; 28.5-27.5\left(\mathrm{Si}_{-} \mathrm{CH}_{2}-\underline{\mathrm{CH}}_{2}-\mathrm{S}\right) ; 26.9\left(\underline{\mathrm{CH}}_{3}-\right.$ $\mathrm{NH}) ; 18.2\left(\mathrm{Si}_{-} \mathrm{CH}_{2}-\mathrm{CH}_{2}-\mathrm{S}\right) ; 2.1,1.6$ to 1.2 and 0.4 to $-0.2\left(\mathrm{H}_{3} \underline{\mathrm{C}}-\mathrm{Si}\right)$.

\section{B: Poly (methyl-phenylethylthioethyl-co-dimethyl) siloxane, P(PhM-co-DM)S}

For the reaction with 2-phenylethanethiol 5, $1 \mathrm{~g}(7.5 \mathrm{mmol})$ of thiol is introduced with $1.0 \mathrm{~g}$ of $\mathrm{P}(\mathrm{VM}$-co-DM)S 3 (13 mmol, $3 \mathrm{mmol}$ of vinyl groups) and $92 \mathrm{mg}(0.6 \mathrm{mmol}, 7 \% \mathrm{~mol} /$ thiol $)$ of AIBN in $4 \mathrm{~mL}$ toluene. The polymer is purified by precipitation in cold acetonitrile. The crude product is added dropwise into acetonitrile at $-20^{\circ} \mathrm{C}$ and left at $-20^{\circ} \mathrm{C}$ for $3 \mathrm{~h}$. This operation is repeated three times, each time removing the acetonitrile. The polymer is precipitated at the bottom of the flask. After drying a colorless transparent viscous liquid is obtained. SEC: retention time $(\mathrm{RI}$ detector $)=23 \mathrm{~min} . \mathrm{dn} / \mathrm{dc}=-0.076$. Yield: $95 \%$.

NMR ${ }^{1} \mathrm{H}\left(\mathrm{CDCl}_{3}\right): \delta$ ppm: 7.35-7.20 (m, Cㅂarom(m), 2H); 7.20-7.10 (m, Cㅂarom(o,p), 3H); 2.90-2.80 (m, S-CH $2-\underline{\mathrm{H}}_{2}$-Carom, 2H); 2.80-2.70 (m, S-C $\left.\underline{\mathrm{H}}_{2}-\mathrm{CH}_{2}-\mathrm{Carom}, 2 \mathrm{H}\right) ; 2.65-2.55$ (m, $\mathrm{Si}-\mathrm{CH}_{2}-\mathrm{CH}_{2}-\mathrm{S}, 2 \mathrm{H}$ ); $1.00-0.80$ (m, Si-C $\left.\underline{\mathrm{H}}_{2}-\mathrm{CH}_{2}-\mathrm{S}, 2 \mathrm{H}\right)$; -0.10 to 0.24 (m, $\left.\underline{\mathrm{H}}_{3} \mathrm{C}-\mathrm{Si}, 25 \mathrm{H}\right)$. NMR ${ }^{29} \mathrm{Si}\left(\mathrm{CDCl}_{3}+0.03 \mathrm{M} \mathrm{Cr}(\mathrm{acac})_{3}\right): \delta$ ppm: 6 to $9\left(\mathrm{~m},\left(\mathrm{CH}_{3}\right)_{3}-\mathrm{Si}-\mathrm{O}-, 0.12 \mathrm{Si}\right) ;-18$ to $-23(\mathrm{~m}, \mathrm{O}-$ $\left.\left(\mathrm{CH}_{3}\right)_{2}-\mathrm{Si}-\mathrm{O}, 3 \mathrm{Si}\right) ;-23$ to $-27\left(\mathrm{~m}, \mathrm{CH}_{3}\left(\mathrm{CH}_{2}-\mathrm{CH}_{2} \mathrm{~S}\right) \mathrm{Si}-\mathrm{O}-, 1 \mathrm{Si}\right) ;-28$ to -30 (traces, $0.03 \mathrm{Si}$ ); -65 to -67 (traces, $\mathrm{CH}_{3} \mathrm{SiO},-\mathrm{O},-\mathrm{OSi}, 0.15 \mathrm{Si}$ ). $\mathrm{NMR}{ }^{13} \mathrm{C}\left(\mathrm{CDCl}_{3}\right)$ : $\delta$ ppm: 140.5 (Carom); 128.8 $(\underline{\mathrm{CH}} \operatorname{arom}(\mathrm{o}, \mathrm{m}))$ ); $126.6(\underline{\mathrm{CH}} \mathrm{Harom}(\mathrm{p})) ; 36.6\left(\mathrm{~S}-\mathrm{CH}_{2}-\underline{\mathrm{CH}}_{2}-\mathrm{Ph}\right) ; 33.9-33.7\left(\mathrm{~S}-\underline{\mathrm{CH}}_{2}-\mathrm{CH}_{2}-\mathrm{Ph}\right) ; 27.0$ $\left(\mathrm{Si}-\mathrm{CH}_{2}-\underline{\mathrm{CH}}_{2}-\mathrm{S}\right) ; 18.6\left(\mathrm{Si}-\underline{\mathrm{C}} \mathrm{H}_{2}-\mathrm{CH}_{2}-\mathrm{S}\right) ; 1.4,0.0\left(\mathrm{H}_{3} \underline{\mathrm{C}}-\mathrm{Si}\right)$ 


\section{C: Poly (methyl-perfluorooctylethylthioethyl-co-dimethyl) siloxane, P(FM-co-DM)S}

$\lg (2 \mathrm{mmol})$ of $3,3,4,4,5,5,6,6,7,7,8,8,9,9,10,10,10$-heptadecafluoro-1-decanethiol $\mathbf{6}$ is introduced with $0.63 \mathrm{~g}$ of P(VM-co-DM)S 3 ( $8.2 \mathrm{mmol}, 1.9 \mathrm{mmol}), 70 \mathrm{mg}$ AIBN (0.4 mmol, $20 \% \mathrm{~mol} /$ thiol). The polymer precipitates after the temperature decreases to room temperature. The precipitate is washed with toluene, by heating the mixture with the polymer and then precipitating it by placing it at $-20^{\circ} \mathrm{C}$. This operation is repeated three times. After drying, a iridescent pale yellow viscous liquid is obtained. SEC: retention time (RI detector) $=22 \mathrm{~min}$. $\mathrm{dn} / \mathrm{dc}=-0,276$. Yield: $43 \%$.

$\mathrm{NMR}{ }^{1} \mathrm{H}\left(\mathrm{CDCl}_{3}\right): \delta_{\mathrm{ppm}}: 2.80-2.70\left(\mathrm{~m}, \mathrm{~S}-\mathrm{CH}_{2}-\mathrm{C}_{2}-\mathrm{CF}_{2}, 2 \mathrm{H}\right) ; 2.70-2.58\left(\mathrm{~m}, \mathrm{~S}-\mathrm{CH}_{2}-\mathrm{CH}_{2}-\mathrm{CF}_{2}\right.$, $2 \mathrm{H}) ; 2.50-2.25$ (m, Si-CH $\left.2-\underline{H}_{2}-\mathrm{S}, 2 \mathrm{H}\right) ; 1.00-0.80$ (s, Si-C $\left.\underline{H}_{2}-\mathrm{CH}_{2}-\mathrm{S}, 2 \mathrm{H}\right) ;-0.1$ to 0.25 (m, $\underline{\mathrm{H}}_{3} \mathrm{C}$ $-\mathrm{Si}, 29 \mathrm{H}) . \mathrm{NMR}^{29} \mathrm{Si}\left(\mathrm{CDCl}_{3}+0.03 \mathrm{M} \mathrm{Cr}(\mathrm{acac})_{3}\right): \delta_{\mathrm{ppm}}: 8.0-7.0\left(\mathrm{~m},\left(\mathrm{CH}_{3}\right)_{3}-\mathrm{Si}-\mathrm{O}, 0.06 \mathrm{Si}\right) ;-20$ to $-23\left(\mathrm{~m},\left(\mathrm{CH}_{3}\right)_{2}-\mathrm{Si}-\mathrm{O}, 3 \mathrm{Si}\right)$; -23 to $-26\left(\mathrm{~m}, \mathrm{CH}_{3}\left(\mathrm{CF}_{3}-\left(\mathrm{CF}_{2}\right)_{7}-\mathrm{CH}_{2}-\mathrm{CH}_{2}-\mathrm{S}-\mathrm{CH}_{2}-\mathrm{CH}_{2}\right)-\mathrm{Si}-\mathrm{O}-\right)$, $0.81 \mathrm{Si}$ ); -34 to -37 (traces, $0.05 \mathrm{Si}$ ). $\mathrm{NMR}{ }^{13} \mathrm{C}(\mathrm{CDCl} 3)$ ): $\delta_{\mathrm{ppm}}: 106$ to 123 (multiples peaks, $\mathrm{CF}_{2}$,

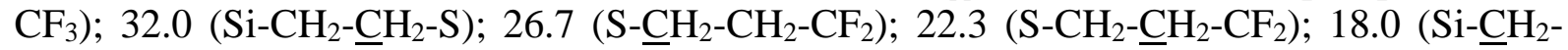
$\left.\mathrm{CH}_{2}-\mathrm{S}\right) ; 2.0,1.0,-0.4\left(\mathrm{H}_{3} \underline{\mathrm{C}}-\mathrm{Si}\right)$.

\section{D: Poly (methyl-N-methylaminocarbonylmethylthioethyl-co-methyl- phenylethylthioethyl-co-dimethyl) siloxane, P(AcM-co-PhM-co-DM)S D}

(N-methyl-mercaptoacetamide $4(120 \mu \mathrm{L}, 1.5 \mathrm{mmol})$ and 2-phenylethanethiol 5 (240 $\mu \mathrm{L}, 1.5$ mmol (50/50)) were introduced in the reaction flask, with $1.0 \mathrm{~g}(13 \mathrm{mmol}, 3 \mathrm{mmol}$ of vinyl groups) of P(VM-co-DM)S 3 and $9 \mathrm{mg}$ of AIBN (2\% mol/thiol). The crude product is added dropwise into acetonitrile at $-20^{\circ} \mathrm{C}$ and left at $-20^{\circ} \mathrm{C}$ for $3 \mathrm{~h}$. This operation is repeated three times, each time removing the acetonitrile. The polymer is precipitated at the bottom of the flask. After drying, a pale yellow viscous liquid is obtained. The two thiols, introduced in equimolar amounts were grafted onto the siloxane backbone with a ratio slightly different from 50/50. Given this small difference and for the sake of clarity, the NMR spectrum has been described for an equimolar grafting of the two thiols. Possible grafting of $\mathrm{N}$ methylmercaptoacetamide in the $\alpha$ position of the vinyl group in masked by the signal of the phenyl thioether. $10 \%$ of unreacted vinyl groups are observed. $\mathrm{dn} / \mathrm{dc}=0.097$. Yield: $50 \%$.

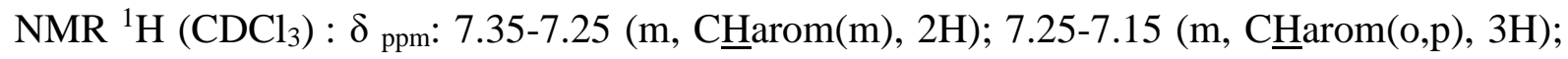

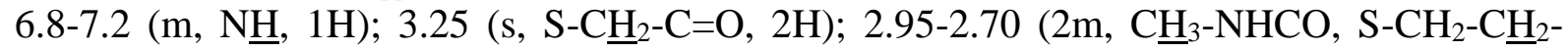
Carom, S-C $\left.\underline{H}_{2}-\mathrm{CH}_{2}-\mathrm{Carom}, 7 \mathrm{H}\right) ; 2.70-2.50$ (m, Si-CH$\left.{ }_{2}-\underline{\mathrm{C}}_{2}-\mathrm{S}, 4 \mathrm{H}\right) ; 1.00-0.80$ (m, Si-C $\underline{\mathrm{H}}_{2}-$ $\left.\mathrm{CH}_{2}-\mathrm{S}, 4 \mathrm{H}\right) ;-0.1$ to $0.25\left(\mathrm{~m}, \underline{\mathrm{H}}_{3} \mathrm{C}-\mathrm{Si}, 52 \mathrm{H}\right) . \mathrm{NMR}^{29} \mathrm{Si}\left(\mathrm{CDCl}_{3}+0.03 \mathrm{M} \mathrm{Cr}(\mathrm{acac})_{3}\right): \delta_{\mathrm{ppm}}: \overline{7}$ to $8\left(\mathrm{~m},\left(\mathrm{CH}_{3}\right)_{3}-\mathrm{Si}-\mathrm{O}, 0.1 \mathrm{Si}\right)$; -20 to $-23\left(\mathrm{~m}, \mathrm{O}-\left(\mathrm{CH}_{3}\right)_{2}-\mathrm{Si}-\mathrm{O}, 3 \mathrm{Si}\right)$; -23 to $-27\left(\mathrm{~m}, \mathrm{CH}_{3}\left(\mathrm{CH}_{2}-\right.\right.$

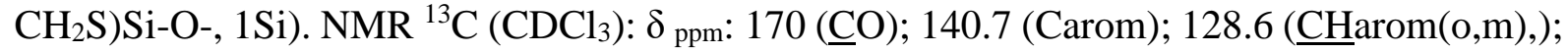
126.3 (CHarom(p)); 36.3, $36.0\left(\mathrm{~S}-\mathrm{CH}_{2}-\underline{\mathrm{CH}}_{2}-\mathrm{Ph}, \underline{\mathrm{S}}-\underline{\mathrm{CH}}_{2}-\mathrm{CO}\right) ; 33.5\left(\mathrm{~S}-\underline{\mathrm{CH}}_{2}-\mathrm{CH}_{2}-\mathrm{Ph}\right) ; 27.0-28.0$ $\left(\mathrm{Si}-\mathrm{CH}_{2}-\underline{\mathrm{CH}}_{2}-\mathrm{S}\right) ; 26.9\left(\underline{\mathrm{CH}}_{3}-\mathrm{NH}\right) ; 18.3\left(\mathrm{Si}-\underline{\mathrm{CH}}_{2}-\mathrm{CH}_{2}-\mathrm{S}(\mathrm{Ph})\right) ; 17.9\left(\mathrm{Si}_{-} \underline{\mathrm{CH}}_{2}-\mathrm{CH}_{2}-\mathrm{S}(\mathrm{Ac})\right) ; 1.8$, $1.1,-0.3\left(\mathrm{H}_{3} \underline{\mathrm{C}}-\mathrm{Si}\right)$. 


\section{E: Poly (methyl-N-methylaminocarbonylmethylthioethyl-co-methyl- perfluorooctylethylthioethyl-co-dimethyl) siloxane, P(AcM-co-FM-co-DM)S}

$\mathrm{N}$-methylmercaptoacetamide $4(150 \mu \mathrm{L}, 1.7 \mathrm{mmol})$ and 3,3,4,4,5,5,6,6,7,7,8,8,9,9,10,10,10heptadecafluoro-1-decanethiol 6 (815 mg, $1.7 \mathrm{mmol})$, and 1g P(VM-co-DM)S 3 (13 mmol, 3 mmol of vinyl groups), $43 \mathrm{mg}(0.3 \mathrm{mmol}, 17 \% \mathrm{~mol} / \mathrm{thiol})$ AIBN are introduced in $4 \mathrm{~mL}$ of toluene. The polymer precipitates after the temperature decreases to room temperature. The toluene is removed and the precipitate is washed again with toluene then recovered and dried under vacuum. $\mathrm{dn} / \mathrm{dc}=0.023$. The NMR signals from the fluorinated group or the mercaptoacetamide group integrate for $1 / 1$. Possible grafting of N-methylmercaptoacetamide in the $\alpha$ position of the vinyl group is masked by the signal of the fluorinated thioether.

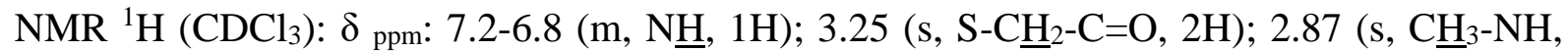
$3 \mathrm{H}) ; 2.80-2.70$ (m, S-CH $\left.{ }_{2}-\mathrm{CH}_{2}-\mathrm{CF}_{2}, 2 \mathrm{H}\right) ; 2.70-2.50$ (m, S-C $\underline{\mathrm{H}}_{2}-\mathrm{CH}_{2}-\mathrm{CF}_{2}, \mathrm{Si}_{-} \mathrm{CH}_{2}-\mathrm{CH}_{2}-\mathrm{S}-\mathrm{CH}_{2}-$ $\mathrm{CO}, 4 \mathrm{H}) ; 2.50-2.30$ (m, Si- $\left.\mathrm{CH}_{2}-\mathrm{CH}_{2}-\mathrm{S}_{-}-\mathrm{CH}_{2}-\mathrm{CH}_{2}-\mathrm{CF}_{2}, 2 \mathrm{H}\right) ; 1.00-0.80$ (m, Si-C $\left.\underline{\mathrm{H}}_{2}-\mathrm{CH}_{2}-\mathrm{S}, 4 \mathrm{H}\right)$; $\left.0.30-0.00\left(\mathrm{~m}, \underline{\mathrm{H}}_{3} \mathrm{C}-\mathrm{Si}, 37 \mathrm{H}\right) . \mathrm{NMR}^{29} \mathrm{Si}\left(\mathrm{CDCl}_{3}+0.03 \mathrm{M} \mathrm{Cr}(\mathrm{acac})_{3}\right)\right): \delta \mathrm{ppm}: 7$ to $8\left(\mathrm{~m},\left(\mathrm{CH}_{3}\right)_{3}-\right.$ $\mathrm{Si}-\mathrm{O}, 0.06 \mathrm{Si})$; -20 to -23 (m, $\left.\mathrm{Si}\left(\mathrm{CH}_{3}\right)_{2}, 3 \mathrm{Si}\right)$; -23 to -27 (m, $\mathrm{SiCH}_{3}\left(\mathrm{CH}_{2}-\mathrm{CH}_{2}-\mathrm{S}-\right)-\mathrm{O}, \mathrm{SiCH}_{3}\left(\mathrm{CF}_{3}-\right.$ $\left.\left.\left(\mathrm{CF}_{2}\right)_{7}-\mathrm{CH}_{2}-\mathrm{CH}_{2}-\mathrm{S}-\mathrm{CH}_{2}-\mathrm{CH}_{2}\right)-\mathrm{O}-, 1 \mathrm{Si}\right)$.

\section{Preparation of spherical nanoparticles ${ }^{[14]}$ :}

$35 \mu \mathrm{L}$ of freshly prepared $\mathrm{NaOH}\left(1 \mathrm{~mol} \cdot \mathrm{L}^{-1}\right)$ solution were added to $18.8 \mathrm{~mL}$ of ultrapure water under magnetic stirring. Then $1 \mathrm{~mL}$ of $\mathrm{HAuCl}_{4} 0.01 \mathrm{~mol} \cdot \mathrm{L}^{-1}$ solution was added, the solution became pale yellow. Finally $100 \mu \mathrm{L}$ of freshly prepared $\mathrm{NaBH}_{4} 0.1 \mathrm{~mol} \cdot \mathrm{L}^{-1}$ were added under vigorous stirring. The solution changed from pale yellow to deep red immediately. $[\mathrm{NaOH}] /\left[\mathrm{NaBH}_{4}\right] /\left[\mathrm{HAuCl}_{4}\right]=3.5 / 1 / 1$. Typical TEM analysis of these nanoparticles is given in figure $\mathrm{x}$. NPS diameter was found equal to $5 \pm 1 \mathrm{~nm}$. From dynamic light scattering a hydrodynamic diameter of $10 \mathrm{~nm}$ was measured. These nanoparticles have a plasmon resonance band centered at $520 \mathrm{~nm}$ that does not evolve significantly after several weeks. Therefore the solution remains stable for weeks.

\section{Preparation of branched nanoparticles ${ }^{[92]}$}

In a typical synthesis, $400 \mu \mathrm{L}$ of an aqueous solution of $\mathrm{NaOH}\left(1 \mathrm{~mol} \cdot \mathrm{L}^{-1}\right), 5 \mathrm{~mL}$ of a glucosamine $\cdot \mathrm{HCl}$ solution $\left(10^{-1} \mathrm{~mol} . \mathrm{L}^{-1}\right)$ and $5 \mathrm{~mL}$ solution of $\mathrm{HAuCl}_{4}\left(10^{-2}\right.$ mol. $\left.\mathrm{L}^{-1}\right)$ were mixed in $90 \mathrm{~mL}$ of ultrapure $\mathrm{H}_{2} \mathrm{O}$. Within 30 minutes, solutions with magnetic stirring at $25^{\circ} \mathrm{C}$, experienced color transition from colorless to purple-blue. Gold nanostars were then studied and used without further purifications steps.

\section{Preparation of polysiloxane-gold nanoparticle hybrids}

Solutions of the following polysiloxanes: $\mathrm{P}(\mathrm{VM}-\mathrm{co}-\mathrm{DM}) \mathrm{S} \mathrm{3}, \mathrm{P}(\mathrm{AcM}-\mathrm{co}-\mathrm{DM}) \mathrm{S}$ A, P(PhM-co$\mathrm{DM}) \mathrm{S} \mathbf{B}, \mathrm{P}(\mathrm{FM}-\mathrm{co}-\mathrm{DM}) \mathrm{S} \mathbf{C}$ were prepared at $10^{-4} \mathrm{wt} \%$ in toluene. $50 \mu \mathrm{L}$ of the polymer solutions was poured into tubes and the toluene was evaporated at room temperature 1 day so that a polymer film was obtained. $3 \mathrm{~mL}$ of nanoparticles solutions (spherical or branched) were dispersed in each tube. UV / Visible spectra were recorded 24 hours later. 


\section{Acknowledgements}

This work has been supported by a grant from "Ministère de l'Education et de la Recherche", France for S.L. We acknowledge P. Lavedan, C. Toppan, M. Vedrenne (NMR Platform of the Toulouse Institute of Chemistry, ICT) for NMR and Bruno Payré, Isabelle Fourquaux, Dominique Goudounèche from CMEAB (Centre de Microscopie Electronique Appliquée à la Biologie, Toulouse) for TEM images, Charles-Louis Serpentini (IMRCP) for spectroscopy. Camille François is acknowledged for experimental support.

\section{Author contribution statement}

JDM and JF conceived and designed the research topic and the experiments, SL performed the experiments, SL, JDM and JF analyzed the data and wrote the paper.

\section{References}

[1] A. R. Sadrolhosseini, S. Shafie, Y. W. Fen, 'Nanoplasmonic Sensor Based on Surface Plasmon-Coupled Emission: Review', Appl. Sci. 2019, 9, 1497.

[2] X. Ma, S. He, B. Qiu, F. Luo, L. Guo, Z. Lin, 'Noble Metal Nanoparticle-Based Multicolor Immunoassays: An Approach toward Visual Quantification of the Analytes with the Naked Eye', ACS Sens. 2019, 4, 782-791.

[3] M. Grzelczak, L. M. Liz-Marzán, R. Klajn, 'Stimuli-responsive self-assembly of nanoparticles', Chem. Soc. Rev. 2019, 48, 1342-1361.

[4] H. Tada, 'Size, shape and interface control in gold nanoparticle-based plasmonic photocatalysts for solar-to-chemical transformations', Dalton Trans. 2019, 48, 63086313.

[5] P. Hervés, M. Pérez-Lorenzo, L. M. Liz-Marzán, J. Dzubiella, Y. Lu, M. Ballauff, 'Catalysis by metallic nanoparticles in aqueous solution: model reactions', Chem. Soc. Rev. 2012, 41, 5577-5587.

[6] M. Beija, E. Palleau, S. Sistach, X. G. Zhao, L. Ressier, C. Mingotaud, M. Destarac, J. D. Marty, 'Control of the catalytic properties and directed assembly on surfaces of MADIX/RAFT polymer-coated gold nanoparticles by tuning polymeric shell charge', $J$. Mater. Chem. 2010, 20, 9433-9442.

[7] J. Beik, M. Khateri, Z. Khosravi, S. K. Kamrava, S. Kooranifar, H. Ghaznavi, A. Shakeri-Zadeh, 'Gold nanoparticles in combinatorial cancer therapy strategies', Coord. Chem. Rev. 2019, 387, 299-324.

[8] J. B. Vines, J.-H. Yoon, N.-E. Ryu, D.-J. Lim, H. Park, 'Gold Nanoparticles for Photothermal Cancer Therapy', Front Chem 2019, 7, DOI 10.3389/fchem.2019.00167.

[9] L. A. Dykman, N. G. Khlebtsov, 'Multifunctional gold-based nanocomposites for theranostics', Biomaterials 2016, 108, 13-34.

[10] M. Yadid, R. Feiner, T. Dvir, 'Gold Nanoparticle-Integrated Scaffolds for Tissue Engineering and Regenerative Medicine', Nano Lett. 2019, 19, 2198-2206.

[11] X. Han, K. Xu, O. Taratula, K. Farsad, 'Applications of nanoparticles in biomedical imaging', Nanoscale 2019, 11, 799-819.

[12] H. W. Tan, J. An, C. K. Chua, T. Tran, 'Metallic Nanoparticle Inks for 3D Printing of Electronics', Adv. Electron. Mater. 2019, 5, 1800831. 
[13] H. Kang, J. T. Buchman, R. S. Rodriguez, H. L. Ring, J. He, K. C. Bantz, C. L. Haynes, 'Stabilization of Silver and Gold Nanoparticles: Preservation and Improvement of Plasmonic Functionalities.', Chem. Rev. 2019, 119, 664-699.

[14] S. Sistach, K. Rahme, N. Perignon, J. D. Marty, N. L. D. Viguerie, F. Gauffre, C. Mingotaud, 'Bolaamphiphile surfactants as nanoparticle stabilizers: Application to reversible aggregation of gold nanoparticles', Chem. Mater. 2008, 20, 1221-1223.

[15] H. H. Nguyen, B. Payré, J. Fitremann, N. Lauth-de Viguerie, J.-D. Marty, 'Thermoresponsive Properties of PNIPAM-Based Hydrogels: Effect of Molecular Architecture and Embedded Gold Nanoparticles', Langmuir 2015, 31, 4761-4768.

[16] I. Pastoriza-Santos, C. Kinnear, J. Pérez-Juste, P. Mulvaney, L. M. Liz-Marzán, 'Plasmonic polymer nanocomposites', Nat. Rev. Mater. 2018, 3, 375.

[17] H. H. Nguyen, A. Brûlet, D. Goudounèche, P. Saint-Aguet, N. L. Viguerie, J.-D. Marty, 'The effect of polymer branching and average molar mass on the formation, stabilization and thermoresponsive properties of gold nanohybrids stabilized by poly $(\mathrm{N}-$ isopropylacrylamides)', Polym. Chem. 2015, 6, 5838-5850.

[18] X. Chen, L. Fang, J. Wang, F. He, X. Chen, Y. Wang, J. Zhou, Y. Tao, J. Sun, Q. Fang, 'Intrinsic High Refractive Index Siloxane-Sulfide Polymer Networks Having High Thermostability and Transmittance via Thiol-Ene Cross-Linking Reaction', Macromolecules 2018, 51, 7567-7573.

[19] M. Chen, G. Zhang, X. Liang, W. Zhang, L. Zhou, B. He, P. Song, X. Yuan, C. Zhang, L. Zhang, H. Yu, H. Yang, 'Thermally stable transparent sol-gel based active siloxaneoligomer materials with tunable high refractive index and dual reactive groups', $R S C$ Adv. 2016, 6, 70825-70831.

[20] M. Pascoal, M. A. Brook, F. Gonzaga, L. Zepeda-Velazquez, 'Thermally controlled silicone functionalization using selective Huisgen reactions', Eur. Polym. J. 2015, 69, 429-437.

[21] R. Bui, M. A. Brook, 'Dynamic covalent Schiff-base silicone polymers and elastomers', Polymer 2019, 160, 282-290.

[22] M. A. Brook, 'New Control Over Silicone Synthesis using SiH Chemistry: The PiersRubinsztajn Reaction', Chem.: Eur. J. 2018, 24, 8458-8469.

[23] A. Fatona, J. Moran-Mirabal, M. A. Brook, 'Controlling silicone networks using dithioacetal crosslinks', Polym. Chem. 2018, 10, 219-227.

[24] A. Genest, D. Portinha, E. Fleury, F. Ganachaud, 'The aza-Michael reaction as an alternative strategy to generate advanced silicon-based (macro)molecules and materials', Progr. Polym. Sci. 2017, 72, 61-110.

[25] M. A. Cole, C. N. Bowman, 'Evaluation of thiol-ene click chemistry in functionalized polysiloxanes', J. Polym. Sci. A: Polym. Chem. 2013, 51, 1749-1757.

[26] M. A. Cole, C. N. Bowman, 'Synthesis and characterization of thiol-ene functionalized siloxanes and evaluation of their crosslinked network properties', J. Polym. Sci. A: Polym. Chem. 2012, 50, 4325-4333.

[27] L. Xue, D. Wang, Z. Yang, Y. Liang, J. Zhang, S. Feng, 'Facile, versatile and efficient synthesis of functional polysiloxanes via thiol-ene chemistry', Eur. Polym. J. 2013, 49, 1050-1056.

[28] P. Lucas, E. Fleury, J.-F. Estur, V. Lapinte, J.-J. Robin, 'Peroxide-Grafted PDMS: Hydrosilylation Reaction and Thiol-Ene Chemistry as an Alternative Pathway', Macromol. Chem. Phys. 2009, 210, 1933-1941.

[29] K. Rózga-Wijas, J. Chojnowski, S. Boileau, 'Optically active dimethylsiloxane copolymers with nucleophilic chiral sulfur groups pendant to the polysiloxane chain', $J$. Polym. Sci. A: Polym. Chem. 1997, 35, 879-888. 
[30] L. Herczynska, L. Lestel, S. Boileau, J. Chojnowski, S. Polowinski, 'Modification of polysiloxanes by free-radical addition of pyridylthiols to the vinyl groups of the polymer', Eur. Polym. J. 1999, 35, 1115-1122.

[31] B. Youssef, L. Lecamp, S. Garin, C. Bunel, 'New synthesis of photocurable silanes and polysiloxanes bearing heterocyclic or olefinic functions', Nucl. Instrum. Methods Phys. Res. B, 1999, 151, 313-317.

[32] D. J. Keddie, J. B. Grande, F. Gonzaga, M. A. Brook, T. R. Dargaville, 'Amphiphilic Silicone Architectures via Anaerobic Thiol-Ene Chemistry’, Org. Lett. 2011, 13, 60066009.

[33] G.-O. Turcan-Trofin, M. Asandulesa, M. Balan-Porcarasu, C.-D. Varganici, V. Tiron, C. Racles, M. Cazacu, 'Linear and cyclic siloxanes functionalized with polar groups by thiol-ene addition: Synthesis, characterization and exploring some material behaviour', J. Mol. Liq. 2019, 282, 187-196.

[34] C. Racles, V. Cozan, A. Bele, M. Dascalu, 'Polar silicones: structure-dielectric properties relationship', Des. Monomers Polym. 2016, 19, 496-507.

[35] M. Skinner, R. Selhorst, T. Emrick, 'Synthesis of water-soluble zwitterionic polysiloxanes', J. Polym. Sci. A: Polym. Chem. 2016, 54, 127-134.

[36] M. Ścibiorek, N. K. Gladkova, J. Chojnowski, 'Controlled synthesis of amphiphilic siloxane-siloxane block copolymers with carboxyl functions', Polym. Bull. 2000, 44, 377-384.

[37] J. Zhang, Y. Chen, M. A. Brook, 'Facile Functionalization of PDMS Elastomer Surfaces Using Thiol-Ene Click Chemistry', Langmuir 2013, 29, 12432-12442.

[38] E. J. Carrasco-Correa, G. Ramis-Ramos, J. M. Herrero-Martínez, M. Lämmerhofer, 'Polymethacrylate monoliths with immobilized poly-3-mercaptopropyl methylsiloxane film for high-coverage surface functionalization by thiol-ene click reaction', $J$. Chromatogr. A 2014, 1367, 123-130.

[39] M. Nowacka, A. Rygała, D. Kręgiel, A. Kowalewska, 'Poly(silsesquioxanes) and poly(siloxanes) grafted with $\mathrm{N}$-acetylcysteine for eradicating mature bacterial biofilms in water environment', Coll. Surf. B: Biointerfaces 2018, 172, 627-634.

[40] S. Ahmed, H. Yang, A. E. Ozcam, K. Efimenko, M. C. Weiger, J. Genzer, J. M. Haugh, 'Poly(vinylmethylsiloxane) Elastomer Networks as Functional Materials for Cell Adhesion and Migration Studies', Biomacromolecules 2011, 12, 1265-1271.

[41] Y. Zuo, Z. Gou, C. Zhang, S. Feng, 'Polysiloxane-Based Autonomic Self-Healing Elastomers Obtained through Dynamic Boronic Ester Bonds Prepared by Thiol-Ene “Click" Chemistry', Macromol. Rapid Comm. 2016, 37, 1052-1059.

[42] Y. Zuo, Z. Gou, J. Zhang, S. Feng, 'Color-Transformable Silicone Elastomers Prepared by Thiol-Ene Reaction with Potential Application in UV-LEDs', Macromol. Rapid Comm. 2016, 37, 597-604.

[43] Y. Zuo, H. Lu, L. Xue, X. Wang, L. Wu, S. Feng, 'Polysiloxane-Based Luminescent Elastomers Prepared by Thiol-ene "Click" Chemistry', Chem.: Eur. J. 2014, 20, 1292412932.

[44] H. Yang, M.-X. Liu, Y.-W. Yao, P.-Y. Tao, B.-P. Lin, P. Keller, X.-Q. Zhang, Y. Sun, L.-X. Guo, 'Polysiloxane-Based Liquid Crystalline Polymers and Elastomers Prepared by Thiol-Ene Chemistry', Macromolecules 2013, 46, 3406-3416.

[45] I. Martínez-Montero, S. Bruña, A. M. González-Vadillo, I. Cuadrado, 'Thiol-Ene Chemistry of Vinylferrocene: A Simple and Versatile Access Route to Novel Electroactive Sulfur- and Ferrocene-Containing Model Compounds and Polysiloxanes', Macromolecules 2014, 47, 1301-1315. 
[46] D. J. Lunn, C. E. Boott, K. E. Bass, T. A. Shuttleworth, N. G. McCreanor, S. Papadouli, I. Manners, 'Controlled Thiol-Ene Functionalization of Polyferrocenylsilane-blockPolyvinylsiloxane Copolymers', Macromol. Chem. Phys. 2013, 214, 2813-2820.

[47] S. J. Dünki, M. Tress, F. Kremer, S. Y. Ko, F. A. Nüesch, C.-D. Varganici, C. Racles, D. M. Opris, 'Fine-tuning of the dielectric properties of polysiloxanes by chemical modification', RSC Adv. 2015, 5, 50054-50062.

[48] C. Zhang, Z. Liu, H. Wang, X. Feng, C. He, 'Novel Anti-Biofouling Soft Contact Lens: 1-Cysteine Conjugated Amphiphilic Conetworks via RAFT and Thiol-Ene Click Chemistry', Macromol. Biosci. 2017, 17, 1600444.

[49] M. Roth, A. Oesterreicher, F. H. Mostegel, A. Moser, G. Pinter, M. Edler, R. Piock, T. Griesser, 'Silicon-based mercaptans: High-performance monomers for thiol-ene photopolymerization', J. Polym. Sci. A: Polym. Chem. 2016, 54, 418-424.

[50] V. A. Kusuma, E. A. Roth, W. P. Clafshenkel, S. S. Klara, X. Zhou, S. R. Venna, E. Albenze, D. R. Luebke, M. S. Mauter, R. R. Koepsel, A. J. Russell, D. Hopkinson, H. B. Nulwala, 'Crosslinked poly(ethylene oxide) containing siloxanes fabricated through thiol-ene photochemistry', J. Polym. Sci. A: Polym. Chem. 2015, 53, 1548-1557.

[51] L. Xue, Y. Zhang, Y. Zuo, S. Diao, J. Zhang, S. Feng, 'Preparation and characterization of novel UV-curing silicone rubber via thiol-ene reaction', Mater. Lett. 2013, 106, 425427.

[52] H. Yang, Q. Zhang, B. Lin, G. Fu, X. Zhang, L. Guo, 'Thermo-sensitive electrospun fibers prepared by a sequential thiol-ene click chemistry approach', J. Polym. Sci. A: Polym. Chem. 2012, 50, 4182-4190.

[53] J. M. Sirrine, A. Zlatanic, V. Meenakshisundaram, J. M. Messman, C. B. Williams, P. R. Dvornic, T. E. Long, '3D Printing Amorphous Polysiloxane Terpolymers via Vat Photopolymerization', Macromol. Chem. Phys. 2019, 220, 1800425.

[54] J. M. Sirrine, V. Meenakshisundaram, N. G. Moon, P. J. Scott, R. J. Mondschein, T. F. Weiseman, C. B. Williams, T. E. Long, 'Functional siloxanes with photo-activated, simultaneous chain extension and crosslinking for lithography-based 3D printing', Polymer 2018, 152, 25-34.

[55] S. Zheng, M. Zlatin, P. R. Selvaganapathy, M. A. Brook, 'Multiple modulus silicone elastomers using 3D extrusion printing of low viscosity inks', Addit. Manuf. 2018, 24, 86-92.

[56] J. Fitremann, W. Moukarzel, M. Mauzac, 'Glycosilicones' in Silicon Based Polymers (Eds.: D.F. Ganachaud, D.S. Boileau, P.B. Boury), Springer Netherlands, 2008, pp. 181202.

[57] W. Moukarzel, J.-D. Marty, D. Appelhans, M. Mauzac, J. Fitremann, 'Synthesis of linear and hyperbranched sugar-grafted polysiloxanes using $N$-hydroxysuccinimideactivated esters', J. Polym. Sci. A: Polym. Chem. 2013, 51, 3607-3618.

[58] T. Rambarran, A. Bertrand, F. Gonzaga, F. Boisson, J. Bernard, E. Fleury, F. Ganachaud, M. A. Brook, 'Sweet supramolecular elastomers from $\alpha, \omega-(\beta$-cyclodextrin terminated) PDMS', Chem. Commun. 2016, 52, 6681-6684.

[59] V. Amendola, R. Pilot, M. Frasconi, O. M. Maragò, M. A. Iatì, 'Surface plasmon resonance in gold nanoparticles: a review', J. Phys.: Condens. Matter 2017, 29, 203002.

[60] H. Chen, T. Ming, L. Zhao, F. Wang, L.-D. Sun, J. Wang, C.-H. Yan, 'Plasmonmolecule interactions', Nano Today 2010, 5, 494-505.

[61] H. Chen, X. Kou, Z. Yang, W. Ni, J. Wang, 'Shape- and Size-Dependent Refractive Index Sensitivity of Gold Nanoparticles', Langmuir 2008, 24, 5233-5237.

[62] S. K. Ghosh, T. Pal, 'Interparticle Coupling Effect on the Surface Plasmon Resonance of Gold Nanoparticles: From Theory to Applications', Chem. Rev. 2007, 107, 4797-4862. 
[63] S. Underwood, P. Mulvaney, 'Effect of the Solution Refractive Index on the Color of Gold Colloids', Langmuir 1994, 10, 3427-3430.

[64] M. D. Malinsky, K. L. Kelly, G. C. Schatz, R. P. Van Duyne, 'Chain Length Dependence and Sensing Capabilities of the Localized Surface Plasmon Resonance of Silver Nanoparticles Chemically Modified with Alkanethiol Self-Assembled Monolayers', J. Am. Chem. Soc. 2001, 123, 1471-1482.

[65] F. H. Ho, Y.-H. Wu, M. Ujihara, T. Imae, 'A solution-based nano-plasmonic sensing technique by using gold nanorods', Analyst 2012, 137, 2545-2548.

[66] L. Tian, E. Chen, N. Gandra, A. Abbas, S. Singamaneni, 'Gold Nanorods as Plasmonic Nanotransducers: Distance-Dependent Refractive Index Sensitivity', Langmuir 2012, 28, 17435-17442.

[67] A. U. Khan, C. Scruggs, D. Hicks, G. Liu, 'Two-Dimensional Plasmonic Nanoparticle as a Nanoscale Sensor to Probe Polymer Brush Formation', Anal. Chem. 2017, 89, 7541-7548.

[68] S. M. Budy, D. J. Hamilton, Y. Cai, M. K. Knowles, S. M. Reed, 'Polymer mediated layer-by-layer assembly of different shaped gold nanoparticles', J. Coll. Interf. Sci. 2017, 487, 336-347.

[69] T. Xie, C. Jing, Y.-T. Long, 'Single plasmonic nanoparticles as ultrasensitive sensors', Analyst 2017, 142, 409-420.

[70] M. D. Baaske, F. Vollmer, 'Optical observation of single atomic ions interacting with plasmonic nanorods in aqueous solution', Nat. Photonics 2016, 10, 733-739.

[71] C.-S. Cheng, Y.-Q. Chen, C.-J. Lu, 'Organic vapour sensing using localized surface plasmon resonance spectrum of metallic nanoparticles self assemble monolayer', Talanta 2007, 73, 358-365.

[72] H. Wei, S. M. H. Abtahi, P. J. Vikesland, 'Plasmonic colorimetric and SERS sensors for environmental analysis', Environ. Sci.: Nano 2015, 2, 120-135.

[73] J. Liu, H. Cai, C. Chen, G. Yang, C.-F. Yang, 'Generation of Localized Surface Plasmon Resonance Using Hybrid Au-Ag Nanoparticle Arrays as a Sensor of Polychlorinated Biphenyls Detection', Sensors (Basel) 2016, 16, DOI 10.3390/s16081241.

[74] N. M. Dissanayake, J. S. Arachchilage, T. A. Samuels, S. O. Obare, 'Highly sensitive plasmonic metal nanoparticle-based sensors for the detection of organophosphorus pesticides', Talanta 2019, 200, 218-227.

[75] B. Sepúlveda, P. C. Angelomé, L. M. Lechuga, L. M. Liz-Marzán, 'LSPR-based nanobiosensors', Nano Today 2009, 4, 244-251.

[76] C.-D. Chen, S.-F. Cheng, L.-K. Chau, C. R. C. Wang, 'Sensing capability of the localized surface plasmon resonance of gold nanorods', Biosens. Bioelectron. 2007, 22, 926-932.

[77] K. M. Mayer, S. Lee, H. Liao, B. C. Rostro, A. Fuentes, P. T. Scully, C. L. Nehl, J. H. Hafner, 'A Label-Free Immunoassay Based Upon Localized Surface Plasmon Resonance of Gold Nanorods', ACS Nano 2008, 2, 687-692.

[78] X. Wang, Y. Li, H. Wang, Q. Fu, J. Peng, Y. Wang, J. Du, Y. Zhou, L. Zhan, 'Gold nanorod-based localized surface plasmon resonance biosensor for sensitive detection of hepatitis B virus in buffer, blood serum and plasma', Biosens. Bioelectron. 2010, 26, 404-410.

[79] A. Abbas, L. Tian, J. J. Morrissey, E. D. Kharasch, S. Singamaneni, 'Hot Spot-Localized Artificial Antibodies for Label-Free Plasmonic Biosensing', Adv. Function. Mater. 2013, 23, 1789-1797.

[80] A. R. Ferhan, J. A. Jackman, J. H. Park, N.-J. Cho, D.-H. Kim, 'Nanoplasmonic sensors for detecting circulating cancer biomarkers', Adv. Drug Deliv. Rev. 2018, 125, 48-77. 
[81] A. Csáki, O. Stranik, W. Fritzsche, 'Localized surface plasmon resonance based biosensing', Expert Rev. Mol. Diagn. 2018, 18, 279-296.

[82] Y.-T. Long, C. Jing, Localized Surface Plasmon Resonance Based Nanobiosensors, Springer-Verlag, Berlin Heidelberg, 2014.

[83] J. Proust, J. Martin, D. Gérard, J.-L. Bijeon, J. Plain, 'Detecting a Zeptogram of Pyridine with a Hybrid Plasmonic-Photonic Nanosensor', ACS Sens. 2019, 4, 586-594.

[84] K. M. Mayer, J. H. Hafner, 'Localized Surface Plasmon Resonance Sensors', Chem. Rev. 2011, 111, 3828-3857.

[85] Y. Xu, P. Bai, X. Zhou, Y. Akimov, C. E. Png, L.-K. Ang, W. Knoll, L. Wu, 'Optical Refractive Index Sensors with Plasmonic and Photonic Structures: Promising and Inconvenient Truth', 2019, 7, 1801433.

[86] B. Špačková, P. Wrobel, M. Bocková, J. Homola, 'Optical Biosensors Based on Plasmonic Nanostructures: A Review', Proc. IEEE 2016, 104, 2380-2408.

[87] J. Boken, P. Khurana, S. Thatai, D. Kumar, S. Prasad, 'Plasmonic nanoparticles and their analytical applications: A review', Appl. Spectrosc. Rev. 2017, 52, 774-820.

[88] S. Szunerits, R. Boukherroub, 'Sensing using localised surface plasmon resonance sensors', Chem. Commun. 2012, 48, 8999-9010.

[89] H. Jans, Q. Huo, 'Gold nanoparticle-enabled biological and chemical detection and analysis', Chem. Soc. Rev. 2012, 41, 2849-2866.

[90] Y. Sun, Y. Xia, 'Increased Sensitivity of Surface Plasmon Resonance of Gold Nanoshells Compared to That of Gold Solid Colloids in Response to Environmental Changes', Anal. Chem. 2002, 74, 5297-5305.

[91] L. Guo, J. A. Jackman, H.-H. Yang, P. Chen, N.-J. Cho, D.-H. Kim, 'Strategies for enhancing the sensitivity of plasmonic nanosensors', Nano Today 2015, 10, 213-239.

[92] W. Moukarzel, J. Fitremann, J.-D. Marty, 'Seed-less amino-sugar mediated synthesis of gold nanostars', Nanoscale 2011, 3, 3285. 